\title{
Seismic and Energy Renovation: A Review of the Code Requirements and Solutions in Italy and Romania
}

\author{
Emil-Sever Georgescu ${ }^{1}$ (D), Mihaela Stela Georgescu ${ }^{2}$, Zina Macri $^{2}$, Edoardo Michele Marino ${ }^{3}$, \\ Giuseppe Margani ${ }^{3}$ (D), Vasile Meita ${ }^{1}$, Radu Pana ${ }^{1}$, Santi Maria Cascone ${ }^{3}$, Horia Petran ${ }^{1}$, \\ Pier Paolo Rossi ${ }^{3}$, Vincenzo Sapienza ${ }^{3, *}$ (i) and Marius Voica ${ }^{2}$ \\ 1 NIRD URBAN-INCERC, Soseaua Pantelimon, nr. 266, 021652, Sector 2, 021652 Bucharest, Romania; \\ emilsevergeorgescu@gmail.com (E.-S.G.); vasile.meita@gmail.com (V.M.); pana.radu@gmail.com (R.P.); \\ hp@incerc2004.ro (H.P.) \\ 2 University of Architecture and Urbanism “Ion Mincu," 010014 Bucharest, Romania; \\ mihaelastela.georgescu@yahoo.com (M.S.G.); zina_and@yahoo.com (Z.M.); mvoika@yahoo.com (M.V.) \\ 3 Department of Civil Engineering and Architecture-University of Catania, via Santa Sofia 64, \\ 95125 Catania, Italy; emarino@dica.unict.it (E.M.M.); margani@unict.it (G.M.); \\ santimariacascone@gmail.com (S.M.C.); prossi@dica.unict.it (P.P.R.) \\ * Correspondence: vsapienza@unict.it; Tel.: +39-0957382531
}

Received: 14 March 2018; Accepted: 1 May 2018; Published: 14 May 2018

\begin{abstract}
Most European cities are characterized by very large areas, often formed by buildings of low quality, from a series of perspectives (architectural, technological, materials, technical systems, etc.). The possibility of renovating them is strategic to improve both the quality of life and to the possibility of economic recovery for building companies. In the last decades, the attention of the scientific community has been addressed to the energy renovation, thanks to the strong activities of the European Community in this field. However, since a relevant part of the EC territory is at risk of earthquake, the possibility to combine both energy and seismic renovation actions may be strategic for many countries. In particular, Italy and Romania are linked by a common social tradition that springs from the Roman Empire. Nowadays, this link is stronger, thanks to common interests in social, cultural and business fields. Therefore, the investigation of possible synergies for seismic and energy renovation strategies may be really interesting for both countries. In this paper, after an overview of regulations and common practices for buildings with reinforced concrete structures, in both states, some key combined renovation interventions will be described and discussed, as well as advantages and perspectives of integrated renovation approaches. The outcomes of this work are to show the way to transform existing energy-consuming and seismic-prone buildings into energy-efficient and seismic-resistant ones.
\end{abstract}

Keywords: building rehabilitation; energy efficiency; seismic reinforcement

\section{Introduction}

Most European cities are characterized by large urban areas, built after the II World War and formed by edifices that often show low standards of quality. The renovation of these districts represents a strategic issue to improve the quality of life and to foster the recovery of the building sector.

In the last decades, the attention of the scientific community has been driven mainly to energy retrofitting, thanks to the strong activities of the European Community in this field. However, a significant number of EU regions is earthquake-prone, as it has been unfortunately shown even in recent time in Greece (2008, 6.4 Mw and 2015, 6.5 Mw), in Serbia (2010, 5.3Mw) and in Spain (2011, 
$5.1 \mathrm{Mw}$ ) [1], as well as in Italy and Romania, as described in detail in Section 2. So, the opportunity to combine energy and seismic renovation turns out to be crucial for many countries.

Italy and Romania, whose real estate is highly energy-consuming [2] and seismically vulnerable [3], may play a breakthrough role.

This paper will review both traditional and innovative renovation interventions devoted in Italy and Romania to enhance the seismic and energy performance of recent buildings, that is, erected from the 1950s through the 1980s, which are generally characterized by reinforced concrete (RC) or steel load bearing structures. The goal is to show the way to transform existing energy-consuming and seismic-prone buildings into energy-efficient and seismic-resistant ones.

Historic edifices [4], that is, built before 1950, need specific measures [5-7] and are not considered in this paper.

\section{State of Art}

\subsection{Overview of Technical Regulations in Italy in Relationship with Earthquake Vulnerability}

The classification of the Italian territory in areas with different levels of seismic hazard started in 1909, after the devastating earthquake that hit the cities of Messina and Reggio Calabria in 1908. The district of Messina and the whole Calabria region were classified as earthquake prone areas and the explicit consideration of the seismic excitation in the design of buildings located in these areas became mandatory [8]. The effect of the earthquake was simulated by equivalent horizontal forces [9]. The level of seismic resistance to be provided to the structure was set to avoid the collapse on the occurrence strong ground motions but damage of structural members caused by such extreme events was admitted. The classification of new seismic areas generally followed the catastrophic events that struck the country over time; for instance, after the Avezzano earthquake in 1915, a portion of the central area in Italy was classified as earthquake prone [10]. Other important seismic events that anticipated the classification of new seismic areas are those that occurred in Abruzzo and the southern area of Marche (1943), the central area of Calabria (1947), Carnia (1959), Velina valley (1961), Irpinia (1962), Monti Nebrodi (1967), Belice valley (1968), Tuscania (1971), Friuli (1976), the southern area of Calabria, Patti gulf (1978), Valnerina (1979) and Irpinia-Basilicata (1980). Today, the whole country is considered earthquake prone and the expected level of seismic excitation is given based on the geographic location of the site (Figure 1). Unfortunately, the most considerable growth of the building stock in Italy took place in seventies when the application of seismic provisions was not mandatory in most of the country. As a consequence, most of the existing buildings supported by a RC frame, which represents the most common technology in Italy [11], have been designed without considering seismic provisions and are affected by important structural deficiencies. In these buildings, resisting elements are mainly arranged in one direction, which makes the structure weak and flexible in the orthogonal direction. Furthermore, the structure if often low ductile at both global and local level, because it tends to form story collapse mechanism and ductile detailings of structural members are missing. Finally, the situation may be aggravated by the use of low quality or time degradation of materials. The seismic upgrading of these buildings is of paramount importance for the safety of the population and the resilience against earthquakes [11].

The Italian Building code provides specific sections for existing buildings. More in detail, provisions for seismic assessment and retrofitting of existing buildings are reported in Section 8 of the "Norme Tecniche per le Costruzioni" (Technical rules for constructions, NTC08) enforced in 2008 [12] and in the relevant section of the associated Commentary [13]. In addition, Section 11 of the Ordinance n. 3431 [14] emanated in 2005 still applies when not in contrast with NTC08. The Italian code is fully consistent with the European building code, which provides the regulations on existing buildings in Eurocode 8 part 3 (EN 1998-3) [15]. Finally, EN 1998 as implemented by means of the relevant National Annexes [16] is also applicable in Italy. The code provisions for existing buildings in force in Italy (i) regulate the procedure for the identification of the structural system and its geometric/mechanical 
features, (ii) define the methods of analysis and their limits of application and (iii) provide instructions for the execution of the safety verifications.

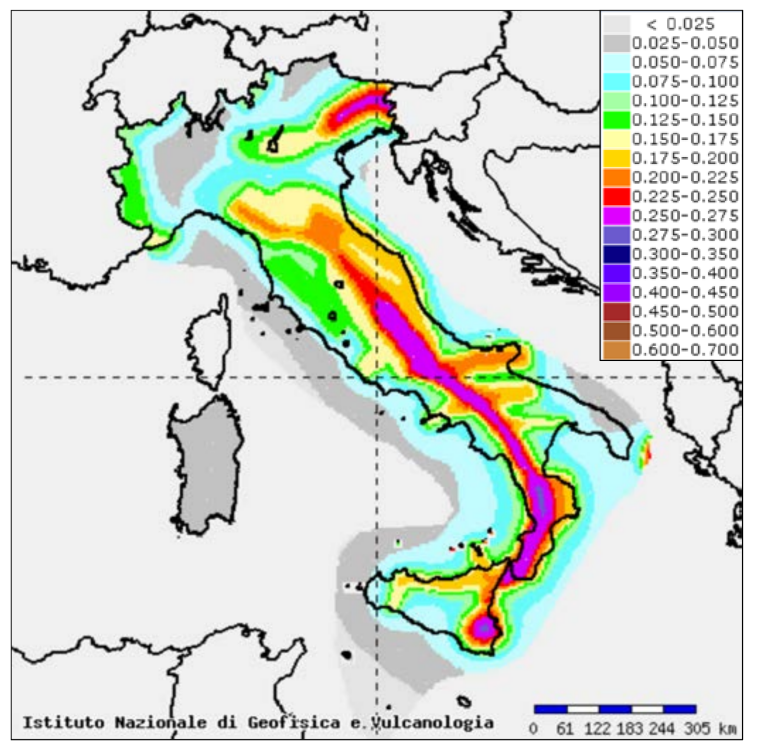

Figure 1. Italian seismic hazard map for probability of exceedance of $10 \%$ in 50 years, Peak Ground Acceleration (PGA) in g.

\subsection{Overview of Technical Regulations in Italy in Relationship with Energy Performance Requirements}

In Italy, the firs regulation for the reduction of the energy consumption in buildings was issued in 1976 (Law 373/1976) [17] but it was low-restrictive an often unattended, due to inadequate controls. The first effective code addressing thermal performance criteria was issued only in 1991 (Law 10/1991) [18], when over $80 \%$ of the current residential stock had been already built [19]. Consequently, most of the Italian real estate is highly energy-consuming [20].

According with its geographic characteristics, Italy has a large variety of climatic conditions (Figure 2) and so, the approach to the energy renovation problems, is very different, along the peninsula. As a simplification, in the northern regions, where the heating demand is prevailing, it is necessary to highly insulate the building envelope [21], while in the southern ones, where conversely the cooling demand is predominant, it is important to take advantage of natural ventilation, external sun-shading devices and massive walls [22,23].

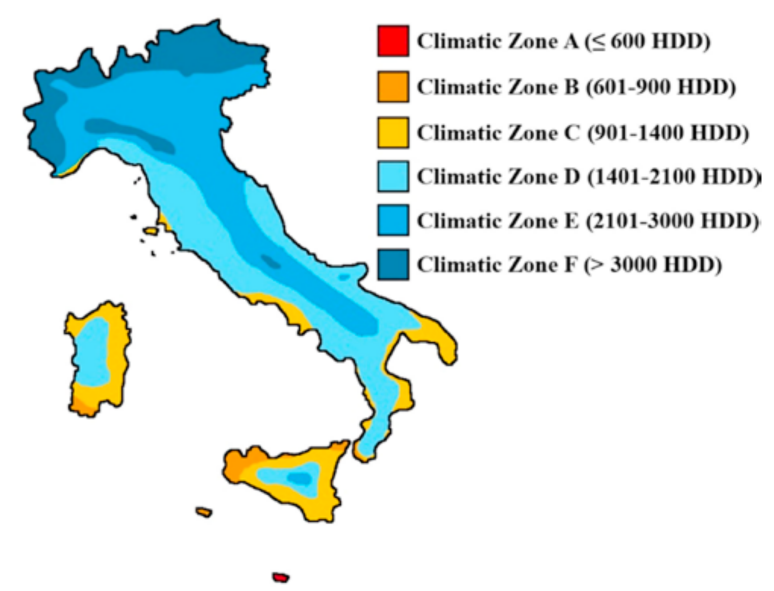

Figure 2. Italian climatic zones, according to the heating degree-days (HDD). 
Today, a recent directive regulates the energy efficiency of new and existing buildings: the Inter-ministerial Decree 26/6/2015 [24].

With particular reference to renovation actions, this directive classifies three levels of interventions:

a. relevant renovations of first level, which involves more than $50 \%$ of the building envelope, as well as the upgrade of the heating and/or cooling system;

b. relevant renovations of second level, which involves $25 / 50 \%$ of the building envelope and may involve also the heating and/or cooling system;

c. energy requalification, which involves less than $25 \%$ of the building envelope and/or the upgrade of the heating and/or cooling system.

In case of interventions (a), the renovated building must have the same energy performance of a new building. In particular, the energy performance must be higher than that of a theoretical so-called "reference building" that has the same location, orientation, use and geometry (shape, volume, surfaces, etc.) of the real building but is characterized by the following U-values for each envelope component (Tables 1 and 2):

Table 1. Thermal transmittance values $\left[\mathrm{W} / \mathrm{m}^{2} \mathrm{~K}\right]$ for the envelope components of the "reference building," currently in force.

\begin{tabular}{cccccc}
\hline \multirow{2}{*}{ Building Components } & \multicolumn{5}{c}{ Climatic Zone } \\
\cline { 2 - 6 } & A, B & C & D & E & F \\
\hline Exterior walls & 0.45 & 0.38 & 0.34 & 0.30 & 0.28 \\
Windows & 3.20 & 2.40 & 2.00 & 1.80 & 1.50 \\
Roofs & 0.38 & 0.36 & 0.30 & 0.25 & 0.23 \\
Ground slab & 0.46 & 0.40 & 0.32 & 0.30 & 0.28 \\
\hline
\end{tabular}

Table 2. Thermal transmittance values $\left[\mathrm{W} / \mathrm{m}^{2} \mathrm{~K}\right]$ for the envelope components of the "reference building," in force from 1 January 2019 for public buildings and from 1 January 2021 for all the other buildings.

\begin{tabular}{cccccc}
\hline \multirow{2}{*}{ Building Components } & \multicolumn{5}{c}{ Climatic Zone } \\
\cline { 2 - 6 } & A, B & C & D & E & F \\
\hline Exterior walls & 0.43 & 0.34 & 0.29 & 0.26 & 0.24 \\
Windows & 3.00 & 2.20 & 1.80 & 1.40 & 1.10 \\
Roofs & 0.35 & 0.33 & 0.26 & 0.22 & 0.20 \\
Ground slab & 0.44 & 0.38 & 0.29 & 0.26 & 0.24 \\
\hline
\end{tabular}

For interventions (b) and (c) the energy performance requirements to be verified regard mainly the thermal characteristics of the portion of the building envelope interested by the renovation works and/or the efficiency of the upgraded systems.

In particular, for (c), the g-values of the windows oriented from East to West (passing through South) must be not higher than 0.35 , while thermal transmittance of the renovated components of the building envelope must be not higher than the following values (Tables 3 and 4):

Table 3. Maximum values of the thermal transmittance $\left[\mathrm{W} / \mathrm{m}^{2} \mathrm{~K}\right]$ of the building envelope components, currently in force.

\begin{tabular}{cccccc}
\hline \multirow{2}{*}{ Building Components } & \multicolumn{5}{c}{ Climatic Zone } \\
\cline { 2 - 6 } & A, B & C & D & E & F \\
\hline Exterior walls & 0.45 & 0.40 & 0.36 & 0.30 & 0.28 \\
Windows & 3.20 & 2.40 & 2.10 & 1.90 & 1.70 \\
Roofs & 0.34 & 0.34 & 0.28 & 0.26 & 0.24 \\
Ground slab & 0.48 & 0.42 & 0.36 & 0.31 & 0.30 \\
\hline
\end{tabular}


Table 4. Maximum values of the thermal transmittance $\left[\mathrm{W} / \mathrm{m}^{2} \mathrm{~K}\right]$ of the building envelope components, in force from 1 January 2019.

\begin{tabular}{cccccc}
\hline \multirow{2}{*}{ Building Components } & \multicolumn{5}{c}{ Climatic Zone } \\
\cline { 2 - 6 } & A, B & C & D & E & F \\
\hline Exterior walls & 0.40 & 0.36 & 0.32 & 0.28 & 0.26 \\
Windows & 3.00 & 2.00 & 1.80 & 1.40 & 1.00 \\
Roofs & 0.32 & 0.32 & 0.26 & 0.24 & 0.22 \\
Ground slab & 0.42 & 0.38 & 0.32 & 0.29 & 0.28 \\
\hline
\end{tabular}

For (b), it is necessary to address the limits set for (c) and, in addition, the transmission heat loss coefficient $\mathrm{H}_{\mathrm{T}}^{\prime}$ of the renovated portion of the building envelope must be not higher than the following values (Table 5):

Table 5. Maximum values of the transmission heat loss coefficient $\mathrm{H}_{\mathrm{T}}^{\prime}\left[\mathrm{W} / \mathrm{m}^{2} \mathrm{~K}\right]$.

\begin{tabular}{ccccc}
\hline \multicolumn{5}{c}{ Climatic Zone } \\
\hline A, B & C & D & E & F \\
\hline 0.73 & 0.70 & 0.68 & 0.65 & 0.62 \\
\hline
\end{tabular}

Moreover, according to the Legislative Decree 28/2011 [25], if the energy renovation involves the entire envelope (external walls, windows, roofs and ground slab) of buildings with a net floor area over $1000 \mathrm{~m}^{2}$, at least $50 \%$ of the energy demand for heating, cooling, Domestic Hot Water (DHW) and electricity must be covered by Renewable Energy Sources (RES).

Finally, according to Law 90/2013 [26], from 2019 all new public buildings and from 2021 all new buildings must reach the nearly Zero Energy Building (nZEB) standard. Of course, this applies also to relevant renovations of first level (a).

\subsection{Overview of Technical Regulations in Romania in Relationship with Earthquake Vulnerability}

The seismic hazard of Romania (Figure 3) is dominated by the Vrancea intermediate depth earthquakes in south-east of the country. This source affects with high intensities ca. $50 \%$ of the territory and is felt with quite important damaging effect on very large areas in neighbouring countries, at each strong event. Romania is a country that is periodically subject to such destructive Vrancea earthquakes, as most recently in 1940 and 1977 [27]. Other crustal (shallow) earthquakes can generate locally very high intensities, with a strong tendency of concentration in west and north.

The November 10, 1940 Vrancea earthquake had a magnitude $\mathrm{M}_{\mathrm{G}-\mathrm{R}}=7.4$ (converted at present at $\left.\mathrm{M}_{\mathrm{w}}=7.6-7.7\right)$ with an epicentral intensity assessed as 10 MCS. The March 4, 1977 Vrancea earthquake had a magnitude $\mathrm{M}_{\mathrm{G}-\mathrm{R}}=7.2$ (converted at present at $\mathrm{M}_{\mathrm{W}}=7.5$ ) and caused damage to a large area and to a variety of buildings. The Building Research Institute (INCERC) seismic record of 4 March 1977 pointed out, for the first time, the spectral content of long period seismic motions of Vrancea earthquakes, the duration, cycle number and higher values of actual accelerations versus code ones, with important effects of overloading upon flexible structures [27-30]. As a consequence of the INCERC record, the spectral curve (the dynamic coefficient $\beta_{\mathrm{r}}$ ), from the P13-1970 Code (which became P100-78), as well as the seismic zonation map of Romanian Standard STAS 2923-63 have been radically changed, with increase of base shear forces. Since then, all areas are seismic.

The new seismic design codes P100-1991, revised 1992, introduced a seismic zonation with two maps, one in terms of seismic coefficient (related to PGA) and another in terms of corner period of the design spectrum, with 3 values. The return period of the map was different in function of the source type.

The procedures for the harmonization between national and European regulations in the field of civil engineering started in Romania in the mid-1990s. Prior to its accession to the European Union (on 1 January 2007), Romania has also followed tightly the programme for the adoption 
of Eurocodes as national standards [31-33]. The Romanian Seismic Design Code P100-1/2006 has prepared the adoption, starting from 2011, of the homologous EN 1998-1, as the Romanian standard SR EN 1998-1, together with its National Annex for Romania and has represented an essential factor in the transition to European norms. The P100-1/2006 Code implements important elements of progress with respect to its previous version, P100-92. The zoning map was set with a return periods of 100 years [31]. The P100-1/2013 Code, introduced a map with 225 years return period. Currently Peak Ground Acceleration (PGA) from $0.10 \mathrm{~g}$ to $0.40 \mathrm{~g}$ are compulsory by the zonation map (Figure 3) [32]. A zonation map with 475 years return period map (EC 8 level) was not yet endorsed, being considered necessary an interval for stakeholders' adaptation.
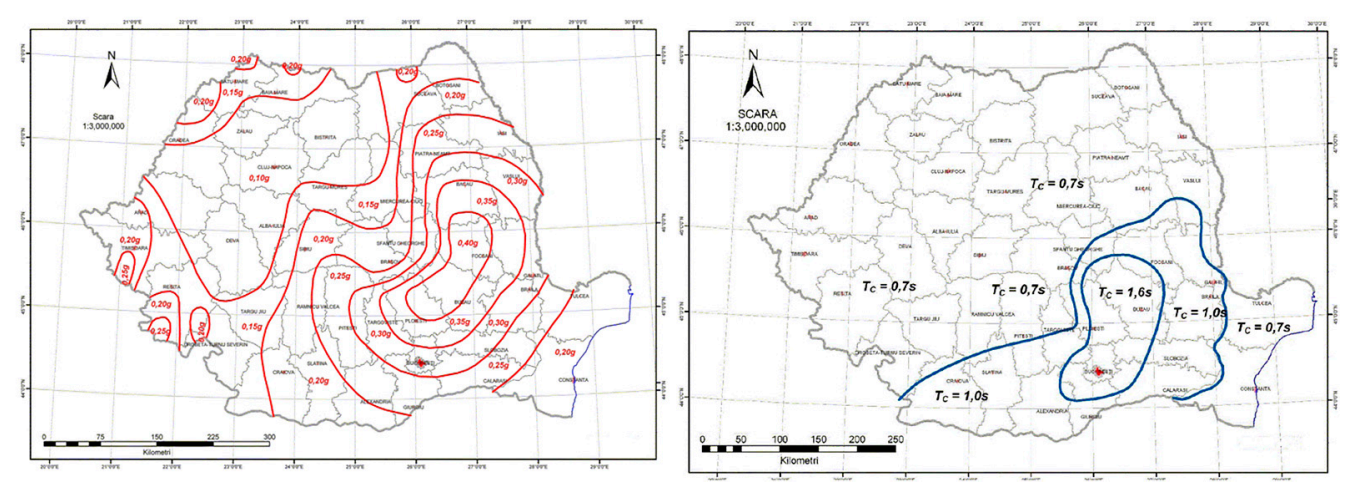

Figure 3. Left: The seismic zoning map of Romania (PGA) for a mean recurrence interval of 225 years and $20 \%$ exceedance probability in 50 years. Right: The seismic zoning map of Romania in terms of Tc-corner periods of the response spectrum (Code P100-1/2013, UTCB [32]).

The Romanian code for the seismic assessment of existing buildings, P100-3/2008, includes several notions and concepts from its European homologue, EN 1998-3. However, Code P100-3 preserves a quantitative approach, based on seismic risk indices, as in code, P100-92 (chapters 11 and 12) and is based on a three-tier approach, similar to that of the ASCE standards [33,34]. The relevant chapters of this code [35] are:

- Generalities; Performance requirements and qualifying criteria;

- Seismic assessment of structures and Non-Structural Components (NSC);

- Collecting the information for structural assessment; Levels of Knowledge (KL1, KL 2, KL3);

- Qualitative assessment; Assessment by calculation (Level 1, 2, 3); Assessment of foundations;

- Final assessment and conclusions;

- Annex A-Performance based seismic assessment of existing buildings;

- Annex B-Reinforced concrete structures; Annex C-Steel structures; Annex D-Masonry structures; Annex E-non-structural components (NSC);

- Annex F (informative)—Guide for seismic rehabilitation of existing buildings (for different materials, energy dissipation systems and base isolation).

\subsection{Overview of Technical Regulations in Romania in Relationship with Energy Performance Requirements}

Technical regulations for the calculation of the thermal protection of the building envelope have been developed since 1961, with standard STAS 6472-61, revised in 1968, 1973, 1975, 1984 (when there is a major change in the insulation requirements of envelope elements-by normative NP-84), 1989.

In 1997, the technical regulation C107-1997 was developed, based on the European and International CEN ISO standards, revised afterwards [36-38]. It introduced the calculation of the thermal resistance values of the envelope elements (1) taking into account the correction due to the effect of thermal bridges ( $R^{\prime}$, which is the inverse thermal transmittance, $U$-value, of a building element), 
evaluated by the linear thermal transmittance $\psi$ and point thermal transmittance $\chi$ (Figure 4). $R$ is the thermal resistance of flat, unlimited elements and A is the area of the considered building element.

$$
\mathrm{R}^{\prime}=\frac{1}{\mathrm{U}^{\prime}}=\frac{1}{\frac{1}{\mathrm{R}}+\frac{\sum \psi \cdot \ell}{\mathrm{A}}+\frac{\sum \mathrm{X}}{\mathrm{A}}}
$$

The calculation of a global heat loss coefficient $G$ of buildings has been introduced, whereby the thermal performance of a building envelope can be assessed by imposing a GN norm ( $G \leq G N)$. The heating energy requirement for buildings in Romania can be judged by the global thermal insulation coefficient $G$ and the average $G$, as follows:

- $\quad 1950-1985-1.00 \mathrm{~W} / \mathrm{m}^{3} \mathrm{~K}$

- $\quad 1986-1997-0.80 \mathrm{~W} / \mathrm{m}^{3} \mathrm{~K}$

- $\quad 1998-2010-0.55 \mathrm{~W} / \mathrm{m}^{3} \mathrm{~K}$
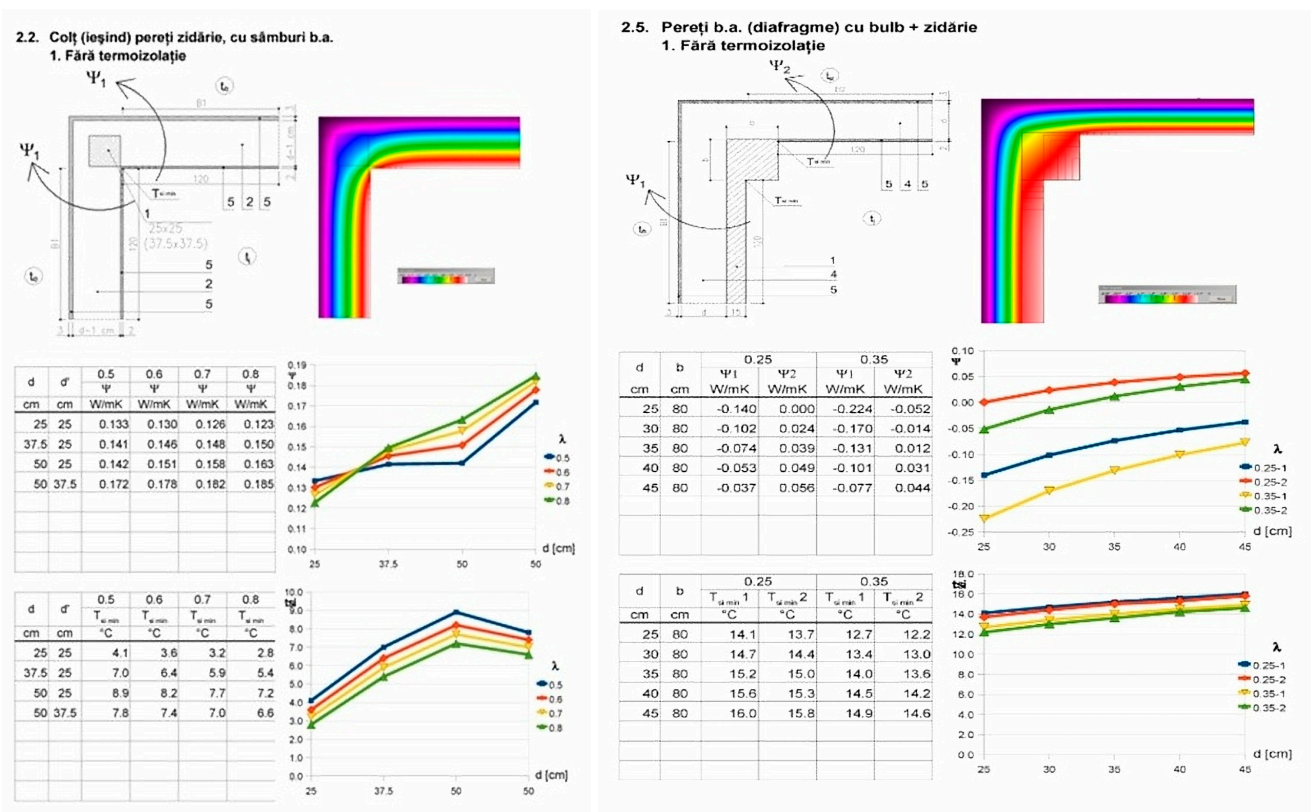

Figure 4. Extract of a thermal bridges catalogue, showing the linear thermal transmittances $\psi$ of a corner with an embedded, uninsulated reinforced concrete (RC) member (column or shear wall) [39].

The climate zonation map in force has 5 zones with design temperatures for Winter (from $-12{ }^{\circ} \mathrm{C}$ to $-24^{\circ} \mathrm{C}$ ) (Figure 5 [40]).

According to 2011 Census, the existing buildings stock of Romania has some 5.3 million buildings, including 8.7 million conventional dwellings. Standardized apartment blocks have a share of up to $70 \%$ of the existing housing stock in some urban areas.

Existing apartment blocks with large panel structure (over 35\% of the total number of blocks until the 1990s) that according to the level of the achieved thermal protection are divided into two categories:

- apartment blocks built according to standard projects until 1985 (approximately 30\% of the built stock) mostly with 5 or 9 stories, having an average G-coefficient of about $1 \mathrm{~W} /\left(\mathrm{m}^{3} \mathrm{~K}\right) /$ average thermal resistances of only $0.6-0.5 \mathrm{~m}^{2} \mathrm{~K} / \mathrm{W}$, which have to be thermally insulated as first measure in energy renovation;

- apartment blocks with 5 stories and 9 stories erected after 1985 according to standard projects (about 7\% of the total built stock) based on the provisions of Decree 256 and NP 15 Normative with a medium thermal resistance increased to about $0.9 \mathrm{~m}^{2} \mathrm{~K} / \mathrm{W}$, characterized by an average global thermal insulation coefficient $\mathrm{G}$ of about $0.8 \mathrm{~W} / \mathrm{m}^{3} \mathrm{~K}$. 


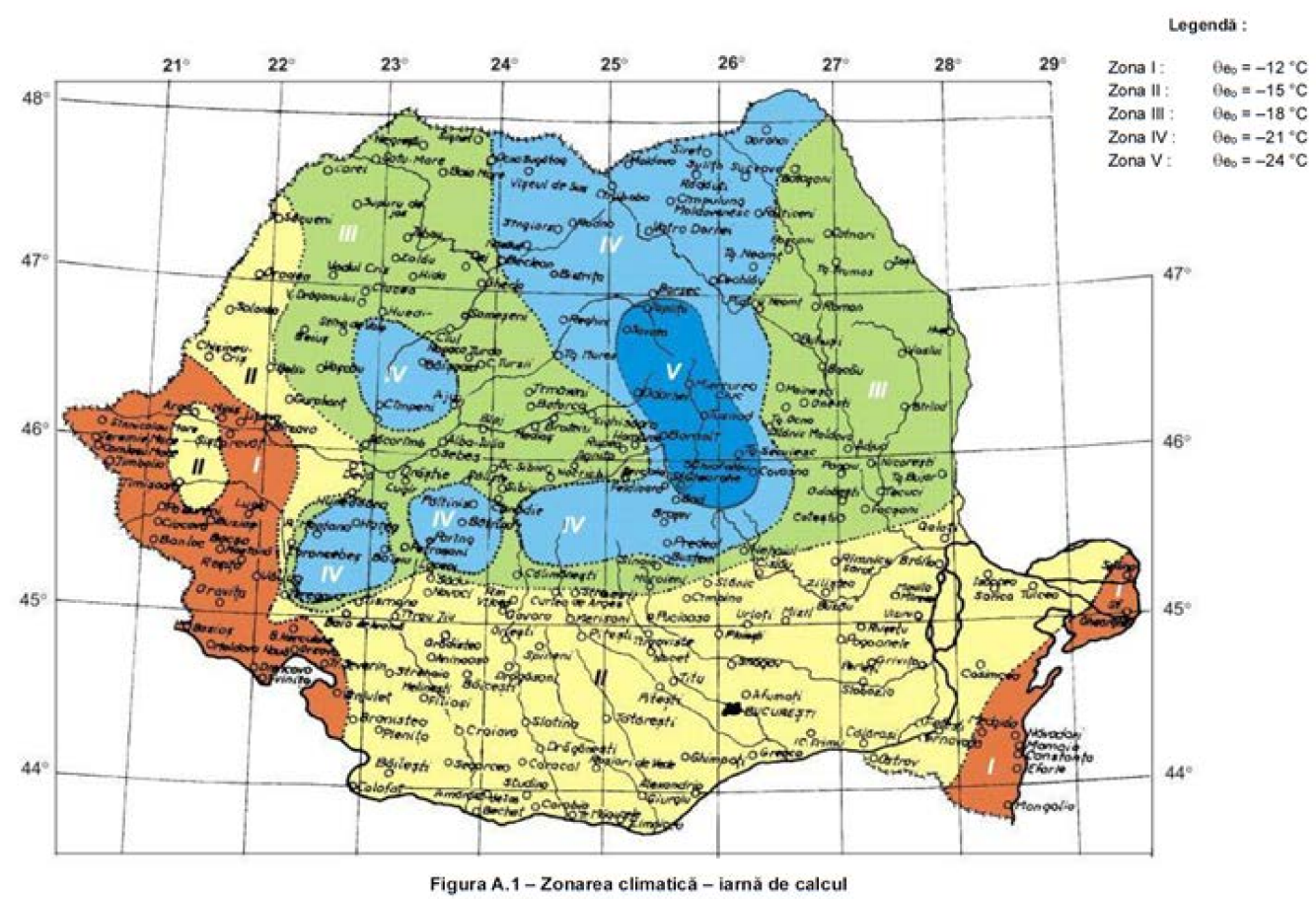

Figure 5. Climatic zonation map of Romania-Winter design temperatures [40].

Structures made of masonry predominate numerically in the dwelling buildings; even in Bucharest. Meanwhile, their number has increased throughout the country.

The level of thermal protection of buildings from the existing building stock corresponds, independently of the structural system used, to the specifications and exigencies imposed during each period, by the technical regulations for the calculation of the thermal performance of the envelope elements. According to each generation of the technical regulations, as well as to the technological level specific to the period, there are groups of buildings with the same level of thermal protection, regardless of the materials used to build the building envelope.

The share of energy consumption in the annual energy balance of an average apartment built between 1970 and 1985 is: heating energy 55.5\%; DHW 9.5\%; drinking water 1.4\%; consumption of natural gas for the preparation of food $9.7 \%$; electricity consumption for lighting $13.9 \%$. Out of the annual energy consumption of a building irrespective of its destination, the heating energy and DHW production represents the main annual energy consumption of about 75\% [40].

The implementation of the European Parliament's Energy Performance of Buildings Directive (EPBD 2002/29/EC, EPBD 2010/31/EC) is also being carried out in Romania in compliance with the provisions of Law no. 372/2005 modified and completed later. A calculation methodology for energy performance of buildings (including the energy certification of buildings and energy audit) was initially based on several norms (2001), later on incorporated in a comprehensive one 2006 [41] and is currently under review. Some other technical guidelines for buildings thermal rehabilitation have been developed, as well as a Catalogue of thermal bridges [39].

For all new buildings it is already mandatory, since 2007, to present the energy performance certificate at the reception of the executed work. For existing buildings that are being rehabilitated, expanded or upgraded, such a certificate must be drawn up. For apartments in residential buildings, the energy performance certificate of the building is mandatory for sale-purchase or lease, from 2010. For public buildings, the energy performance certificate must be exposed at the entrance.

The minimum thermal resistance $-\mathrm{R}_{\text {min }}^{\prime}$ and thermal transmissions $-\mathrm{U}^{\prime}{ }_{\max }$ of the building envelope elements (taking into account the effect of thermal bridges), on the whole of the dwelling 
buildings, designed on the basis of the design contracts concluded after 1 January 2011 [42] is presented in Table 6.

Table 6. The minimum thermal resistance $-\mathrm{R}_{\text {min }}^{\prime}$ and thermal transmissions $-\mathrm{U}^{\prime}{ }_{\max }$ of the building elements, on the whole of the dwelling buildings, designed on the basis of the design contracts concluded after 1 January 2011 [42].

\begin{tabular}{clcc}
\hline \multirow{2}{*}{ Nr. Crt. } & \multicolumn{1}{c}{ Building Components } & \multicolumn{2}{c}{ Residential Buildings } \\
\cline { 3 - 4 } & & $\begin{array}{c}\mathbf{R}^{\prime}{ }_{\min } \\
{\left[\mathbf{m}^{2} \mathbf{K} / \mathbf{W}\right]}\end{array}$ & $\begin{array}{c}\mathbf{U}^{\prime}{ }_{\max } \\
{\left[\mathbf{W} / \mathbf{m}^{2} \mathbf{K}\right]}\end{array}$ \\
\hline 1 & Exterior walls (excluding glazed surfaces, including adjoining walls of open joints) & 1.80 & 0.56 \\
2 & Windows & 0.77 & 1.30 \\
3 & Top slabs above the last level, under terraces or attics & 5.00 & 0.20 \\
4 & Bottom slab over unheated basements and cellars & 2.90 & 0.35 \\
5 & Walls adjacent to closed joints & 1.10 & 0.90 \\
6 & Slabs that delimit the building at the bottom, from the outside (in the bow-windows, & 4.50 & 0.22 \\
7 & passage gangs, etc.) & 4.50 & 0.22 \\
8 & Slabs on the ground (over ground level) & 4.80 & 0.21 \\
9 & Slabs at the bottom of heated semi-basement or basements (under ground level) & 2.90 & 0.35 \\
\hline
\end{tabular}

The Energy Performance of Buildings Directive, issued in 2002 and revised in 2010 (EPBD 2010/31/EC) and the European Directive on the use of RES (RESD 2009/28/EC), were the basis for the drafting of country strategies and government policies, transposed into national laws. The National Plan $[43,44]$ includes the long-term energy efficiency strategy at national level, based on existing legal framework and programs establishing the contribution of the state, the local administration and the owners and specifies the necessary documentation and eligible type of actions. The definition of nZEB in Romania was detailed by the MDRAP Order 386/2016 by officially specifying the performance levels in terms of the maximum admissible level of primary energy from fossil sources and of $\mathrm{CO}_{2}$ emissions resulting from the operation of buildings-by building types and winter climate zones in Romania (Figure 5). The levels will be applied mandatory for all new buildings starting from 2021. The maximum allowed value of the primary energy use (thermal and electric energy supply processes), determined by cost optimal calculations based on reference buildings vary according to the winter climate zoning of Romania (values between brackets correspond to the average climate zone for Romania): 98 to 217 (111) $\mathrm{kWh} / \mathrm{m}^{2} \mathrm{yr}$ for single-family residential buildings, 93 to 135 (100) $\mathrm{kWh} / \mathrm{m}^{2} \mathrm{yr}$ for multi-family apartment buildings, 45 to $89(57) \mathrm{kWh} / \mathrm{m}^{2} \mathrm{yr}$ for office buildings. In order to ensure the total energy use of a nZEB, energy from RES shall account for at least $10 \%$ of the total calculated primary energy of the building.

As intermediary performance values until the enforcement of nZEB obligations for new buildings, the MDRAPFE Order No. 2641/2017 recently established (for the first time in Romania) minimum requirements in terms of maximum primary energy consumption for heating (only). The limits (max primary energy for heating in $\mathrm{kWh} / \mathrm{m}^{2} \mathrm{yr}$ ) vary from 60 for office buildings to 117 (large residential), 149 (hospital) and 153 (small residential). This time, the requirements are applied both for newly built and existing buildings undergoing major renovation.

\section{Seismic Resistance Assessment and Structural Strengthening}

\subsection{Italian Relevant Seismic Codes and Expertise on Seismic Strengthening of the Existing Building Stock}

The identification of the structural system is of paramount importance for a proper assessment of the structure and for the design of retrofit interventions. In fact, usually designers do not know the mechanical features of the materials, size and arrangement of the structural members and quality of structural detailing. Hence, information on these aspects have to be collected from the available documentation, analysis of the codes in force at the time of construction, field investigations and in-situ and/or laboratory measurements. Based on the completeness and reliability of the collected 
information, the structure is assigned to one of three "knowledge levels": limited knowledge (KL1), normal knowledge (KL2) and full knowledge (KL3). The knowledge level of the structure determines method of analysis and numerical model that can be used for the evaluation of the structural response and the values to be adopted for the confidence factors [45] in the safety verifications.

Linear or nonlinear methods of analysis and modelling can be used for the evaluation of the seismic response of the structure. The choice depends on the achieved knowledge level of the structure. Linear structural analysis model (Linear numerical Model analysed by Lateral Force Analysis or Multi-modal Response Spectrum Analysis [46,47]) must be used for knowledge level KL1, while nonlinear structural analysis model (Nonlinear numerical Model analysed by Nonlinear Static Analysis [48,49] or Nonlinear Time-History Analysis [50-52]) may be used if the knowledge level achieved by means of the preliminarily inspection of the structure is KL2 or KL3. Since the collapse mechanism of an existing structure is not known a priori, any member may yield and there is no distinction between dissipative and non-dissipative members. Hence, nonlinear models and methods of analysis, which are able to detect the collapse mechanism and predict the inelastic demand of the members explicitly, should be preferred to the linear ones when applicable.

Criteria for safety verification are given separately for $\mathrm{RC}$, steel, composite and masonry structures. Furthermore, for each type of structure, the Italian code provides two sets of criteria: the first set applies if the seismic response to be assessed has been determined by linear methods of analysis, whereas the second one is used in combination with nonlinear methods of analysis. Criteria for linear methods of analysis are rather conservative to compensate for the low level of accuracy of these methods. Furthermore, the conservativism of the criteria for safety verification is also controlled by the values of the confidence factors, which modify the strength of the members to be considered in the verification. A lower knowledge level means a higher degree of uncertainty of the features of the structure, which is compensated by the use of larger values of confidence factors.

If the seismic response of the structure does not fulfil the standard required by the code, the gap should be filled by seismic upgrading [53]. Increasing the safety level of the building against collapse is the primary goal of retrofit interventions. However, a reduced damage of structural and non-structural elements in the occurrence of moderate earthquakes and a limited disturbance to the occupants of the building during the realization of the retrofit interventions should be considered as further important goals in the choice and application of the retrofit technique. Many strategies may be embraced to pursue these objectives. The most classical way is to increase the strength and/or ductility capacity of the structure at global or local level. For instance, the (global) lateral strength of the structure can be increased by adding new seismic-resistant elements, for example, RC shear walls or steel braced frames. The new resisting elements should be properly connected to the existing structure and stiff enough to draw part of the seismic force. Alternatively, the strength can be increased locally by interventions on individual structural elements; for example, concrete or steel jacketing [54] as well as Fibre Reinforced Polymer (FRP) plating and wrapping [55] can be used to improve the flexural and/or shear strength of RC members. Furthermore, these interventions also allow the enhancement of the ductility capacity of $\mathrm{RC}$ members through the confinement of concrete.

An alternative retrofitting solution is to reduce the seismic demand of the structure by base isolation [56-59]. First, columns are cut off from foundation; then isolators are installed between column bases and foundation. These measures elongate the fundamental period of the structure and thus drastically reduce the seismic force on the structure. This strategy is very effective but cannot be used when the building to be upgraded is contiguous with other buildings. Furthermore, its effectiveness decreases with the aspect ratio. Seismic demand can also be reduced by using dampers [60]. Many kinds of dampers (hysteretic, viscous, viscoelastic, etc.) [61-65] are available on the market and can be embedded in the structure [66-68] or inserted between the structure to be retrofitted and an external reaction structure [69]. Dampers dissipate part of the input energy provided by the earthquake, thereby reducing the displacement demand of the structure. As an example, Figures 6 and 7 show two retrofit interventions on schools in Italy. In particular, Figure 6 
shows the retrofit intervention carried out at the school Cappuccini located in Ramacca at about $50 \mathrm{~km}$ from Catania by means of Buckling Restrained Braces (BRBs). The school was condemned owing to a severe crack pattern present in the non-structural elements after the earthquake that stroke the eastern part of Sicily in 2002. The building was built in the 1970s and endowed with RC moment resisting frames designed for gravity loads only. The BRBs were inserted in the early 2000s to reduce the seismic action effects on the existing structure and dissipate part of the input seismic energy. The BRBs were inserted within some frames located in the central part of the building [70]. Figure 7 instead shows the retrofit intervention carried out at the school Gentile-Fermi located in Fabriano at about $70 \mathrm{~km}$ from Ancona by means of viscoelastic dampers [71]. The building was built in the 1950s and endowed with RC moment resisting frames designed for gravity loads only. The school was condemned after an earthquake occurred in 1997. Like the previous structure, that of the school Gentile-Fermi had insufficient resistance to seismic actions and insufficient local and global ductility. Viscoelastic dampers were chosen to dissipate part of the seismic input energy and limit the increase of the lateral stiffness consequent to the introduction of braces. To reduce the interruption of the functionality of the construction, the viscoelastic dampers were inserted within some frames located on the perimeter of the building.
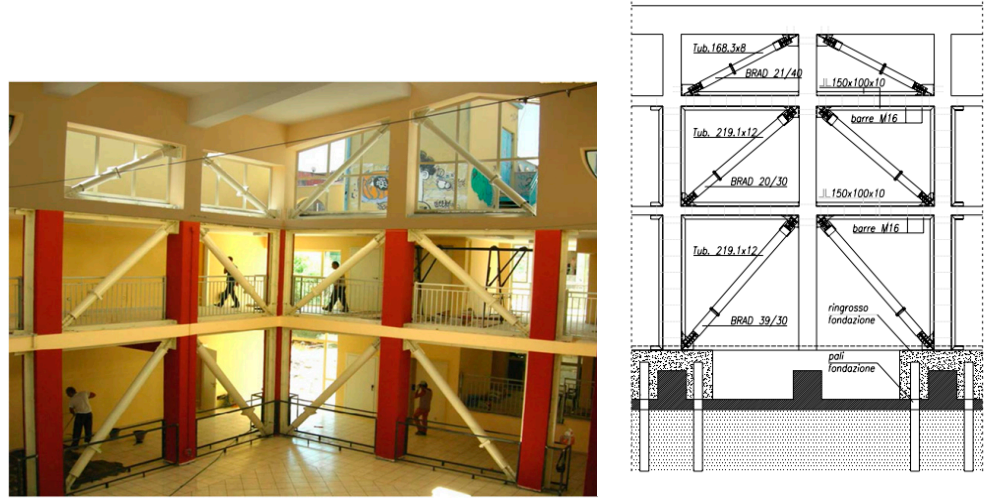

Figure 6. Retrofit intervention by means of buckling restrained braces (BRBs) in the school Cappuccini in Ramacca (Catania).

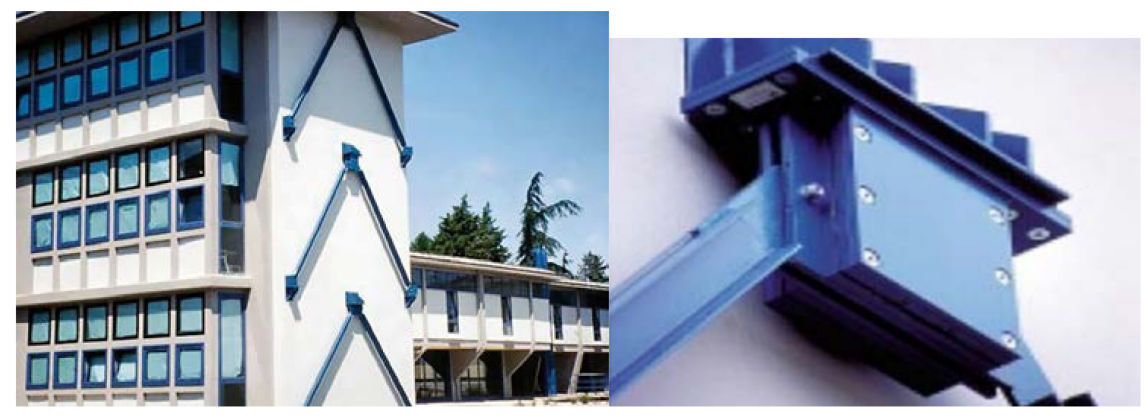

Figure 7. Retrofit intervention by means of viscoelastic dampers in the school Gentile-Fermi in Fabriano (Ancona) [71].

The retrofit intervention is selected based on the analysis of the structural deficiencies. Often, two or more techniques are combined together to achieve the seismic upgrading of the building [72-79]. The great variety of techniques and the need to combine them together represent a further source of difficulty with respect to the case of new structures, for which the designer needs to select just one structural type among a limited number. As an example of a retrofit intervention in which more techniques are combined, Figure 8 shows the retrofit intervention carried out at the school Varano located in Camerino at about $30 \mathrm{~km}$ from Macerata by means of rigid rocking towers and viscous 
dampers patented by Alessandro Balducci [80]. The school was built in the 1960s and consists of two separate constructions. Both are endowed of RC framed structures. The retrofit intervention was completed in 2012 (in about 7 months) without interruption of the school activities. The intervention aimed at dissipating a large amount of energy by means of the viscous dampers at the base of the towers and leave the RC structural elements to be elastic under moderate intensity earthquakes. The two steel braced towers were connected to the decks by means of steel trusses.

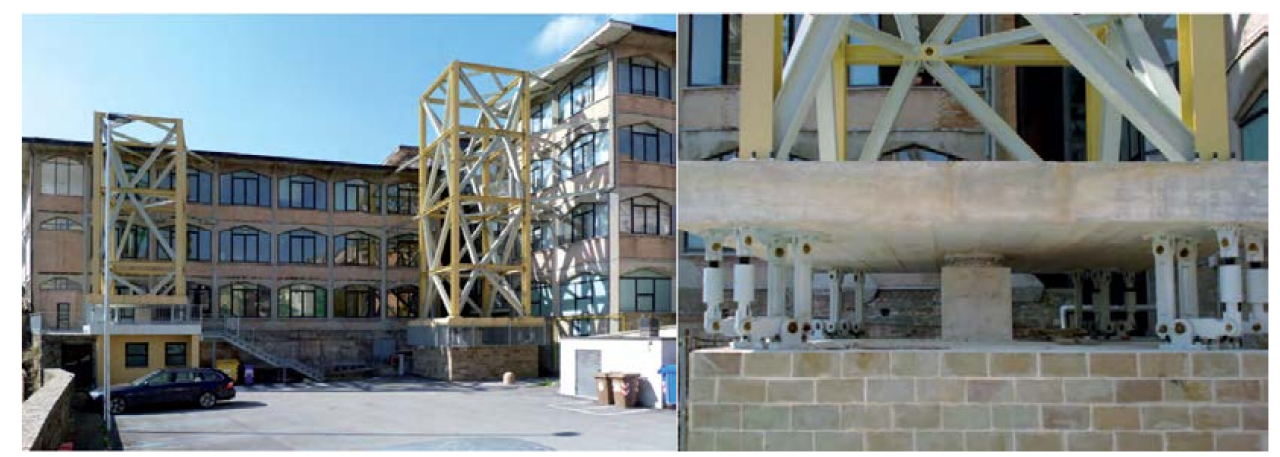

Figure 8. Retrofit intervention by means of dissipative towers and viscous dampers in Camerino (Macerata) [80].

The regulations given in the code are mostly for traditional retrofit interventions, while innovative techniques are not covered by code provisions. This is a gap in the code that will be hopefully filled in the future. Research devoted to standardizing the method of application of these techniques for the seismic upgrading of structures and to formulate design methods for retrofitting interventions able to achieve the performance objectives stipulated in the Italian code are of paramount importance. This research activity could create the background for the new generation of building codes and make innovative technique immediately available. In fact, the Italian building code has been developed in a performance-based framework. The performance objectives are defined through three limit states, namely Near Collapse (NC), Significant Damage (SD) and Damage Limitation (DL). Details on the seismic excitation level that should be considered for the verification of each limit state and acceptance criteria may be found in the relevant part of the Italian building code [13,14] and EN 1998 Part 3 [15]. This allows the use of techniques and design methods that ensure the minimum level of structural safety required by the code, even if these techniques are not explicitly considered in the code.

\subsection{Romanian Relevant Seismic Codes and Expertise on Seismic Strengthening of the Existing Building Stock}

The experience of 1977 Vrancea earthquake is relevant for the situation of existing built stock in terms of features, vulnerability and risk. The most heavily affected category in 1977 was that of the old tall buildings. This situation may be understood mainly in connection with some features of their structural design, which was without or with reduced seismic requirements. Some urban and architectural planning patterns played a role (irregular shape in plane and on vertical). The damage of 1940 earthquake were not repaired, while from 1940 to 1977 the buildings maintenance was neglected. The old, relatively low and stiff, bearing masonry buildings (Figure 9) have shown, as a rule, a better performance, especially in Bucharest and collapses were noticed in isolated cases. The spectral specific of strong motion was an important factor of overloading or reduced loading [27,28]. 


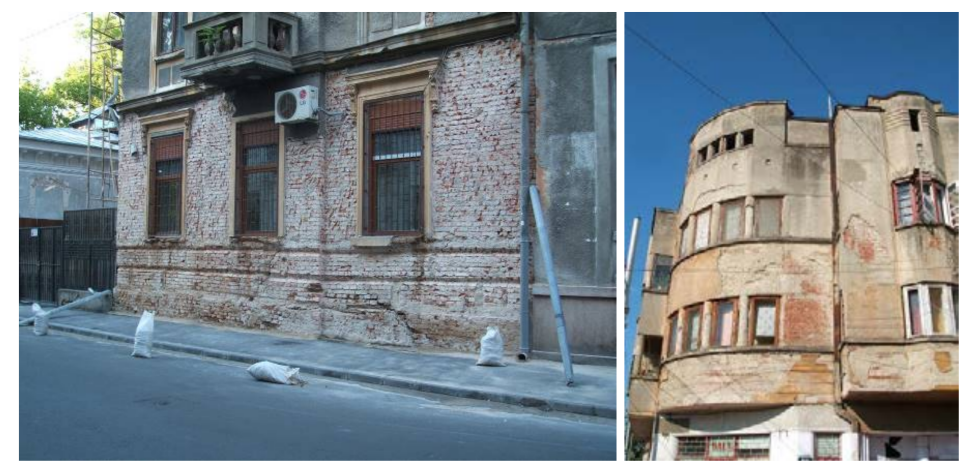

Figure 9. Low-rise and mid-rise masonry buildings, after some 80-100 years.

The new apartment buildings, built after 1950, present a wide diversity of architectural planning and of structural solutions, with many solutions used in standardized design for low-rise buildings (up to 5 stories) and high-rise buildings ( 8 to 18 stories, the most frequent being that of 10-11 stories).

Before 1990, various construction technologies and structural systems, included prefabrication and industrialized forms for cast-in-place concrete. The large panel standardized apartment blocks represented an increasingly important share of the new construction. The performance of these buildings was good or fair in almost all zones for five-story as well as for eight- or nine-story buildings. It is important to say that most of IPCT solutions were tested in INCERC.

The cast-in-place, $R C$ shear wall buildings that present the greatest share among the structural solutions in seismic zones, especially for high-rise buildings, have shown various behaviour patterns, depending on their overall number of stories, on the quality of workmanship and structural solution, as well as on the intensity of shaking. Under such circumstances, five-story buildings have shown a good or fair behaviour, independent of the structural solution adopted (smaller or large intervals between shear walls).

The new RC framed structures, with five or eleven to twelve stories, for which a regular pattern of columns and beams has been provided, have shown generally a much better performance than old buildings (pre-1940) with RC framed structures, for which the place of columns has been an irregular one.

After 4 March 1977, the specialists of INCERC, as well as the great number of civil engineers existing in 1977 in numerous design institutes provided immediate technical guidelines for repair and strengthening. From structural point of view, the most damaged were pre-1940 structures with columns and beams but not moment resisting frames and all other structures designed after 1940's with some seismic code but at more reduced base shear force, as it was the knowledge for each period. But on 30 March 1977 the Government of that time ordered that the existing structures shall be maintained or rehabilitated, nominally, at the initial strength level. On 4 July 1977, it was ordered to make only local repairs. Thus, political orders left Bucharest with a large stock of high-occupancy, high-rise residential buildings that have been damaged by the 1977 (and possibly the 1940) Vrancea earthquake. Most of these buildings, still in use, are at significant risk from future Vrancea earthquakes [30].

The new seismic design codes P100-1991, revised 1992 and 1997, introduced in chapters 11 and 12 the obligation to evaluate buildings and indicate classes of risk, as it is also in Code P100-3/2008, in force, and, if required, to rehabilitate the existing buildings, with some public financing. Buildings of the first class of risk are labelled with a red dot.

By Law, that is, Government Ordinance on Existing Buildings Risk Reduction [81], evaluation of residential buildings resistance (in terms of Code P100-92, later on in Code P100-3/2008) was provided for free, while for design and strengthening works the owner may receive a bank credit at $5 \%$ interest up to 20 years, paid by Government; the apartment owners in buildings of first class of risk, with an income under the country average, may receive full subsidies. 
For high-rise buildings erected before 1940 (Figure 10), conceived without seismic design, the strengthening means a rather general jacketing of existing frames, from foundations to the top, to become moment-resisting ones, ductile and able to withstand lateral forces. This implies local or general evacuation and relocation of occupants for 1 to 2 years. For other 1950-1977 (Figure 11) structural types, designed for lower seismic loads, interventions may be on some specific members or zones, or on several stories. In such cases, some advanced techniques, as frame bracing could be applied, with less need of evacuation.
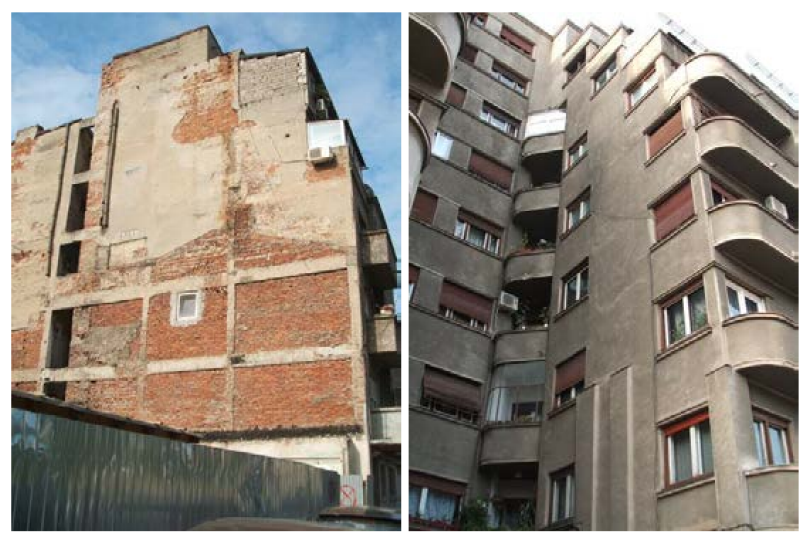

Figure 10. High-rise apartment building, with RC columns and beams, infilled with masonry, erected before 1940. Left side: a building without visible strengthening or renovation. Right side: with local repair, that is, limited and inadequate jacketing of columns, after 4 March 1977 earthquake.

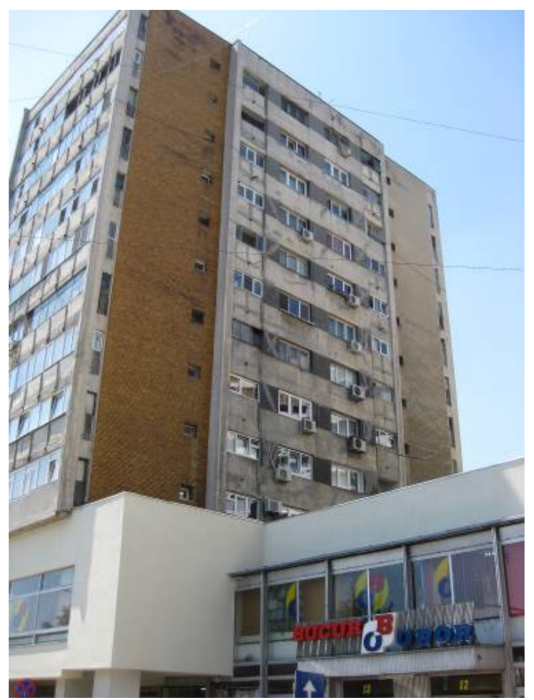

Figure 11. High-rise apartment building erected in the 1970s, having commercial spaces at ground-floor, with visible damages from 4 March 1977 earthquake, before renovation.

\section{Current Technologies for Energy Efficiency}

\subsection{Current Technologies for Energy Efficiency}

The current retrofit technologies used in Italy for enhancing the energy efficiency of buildings can be categorized into three main categories:

(i) heating and cooling demand reduction;

(ii) upgrade of the Heating, Ventilating and Air Conditioning (HVAC) equipment;

(iii) installation of RES technologies. 
To category (i) belong all the interventions that involve the building fabric: envelope insulation (roof, wall, ground floor) [82], windows retrofits (thermal-break frames, multiple glazing, inert gas filling, low-emission coatings, external sun-shading systems, etc.), cool roofs and coating and increased air tightness. To this group one may also add bioclimatic technologies for exploiting natural resources: solar radiation, natural ventilation, evaporative cooling, etc.

Category (ii) includes mostly the improvement of the heating and cooling systems, for example, by installing high efficiency heat pumps, biomass boilers, geothermal power systems, etc.

Finally, category (iii) embraces the integration of different RES systems, such as solar thermal (ST) collectors, PhotoVoltaic (PV) or hybrid PhotoVoltaic and Thermal (PV/T) panels, wind power micro-turbines, etc. [83-86].

In case of relevant renovations of first level (see (a) in Section 2.2.), in Italy, from 2019 (for public buildings) or 2021 (for all other buildings), it will be mandatory to reach the nZEB standard. In this case further strategies should be necessary in some cases, such as the integration into the building envelope of Phase Change Materials (PCM), the use of low conductivity insulation materials (e.g., aerogel, vacuum insulated panels), as well as the use of Building Energy Management Systems (BEMS) [87-90], that is, computer-based control devices that supervise and monitor the mechanical and electrical equipment (e.g., HVAC, RES, household appliances, lighting and power systems) [91,92], according to comfort requirements, occupancy regimes, energy demand and current electricity price.

For each renovation intervention, the implementation cost and the potential benefits are different. Figure 12 shows the intervention costs versus environmental benefits (reduction of $\mathrm{CO}_{2}$ emission). It can be observed, that the installation of RES systems may require high investment costs and low environmental benefits. This is mostly due to the high environmental impact of the disposal of some RES systems (e.g., PV, PV/T) [93].

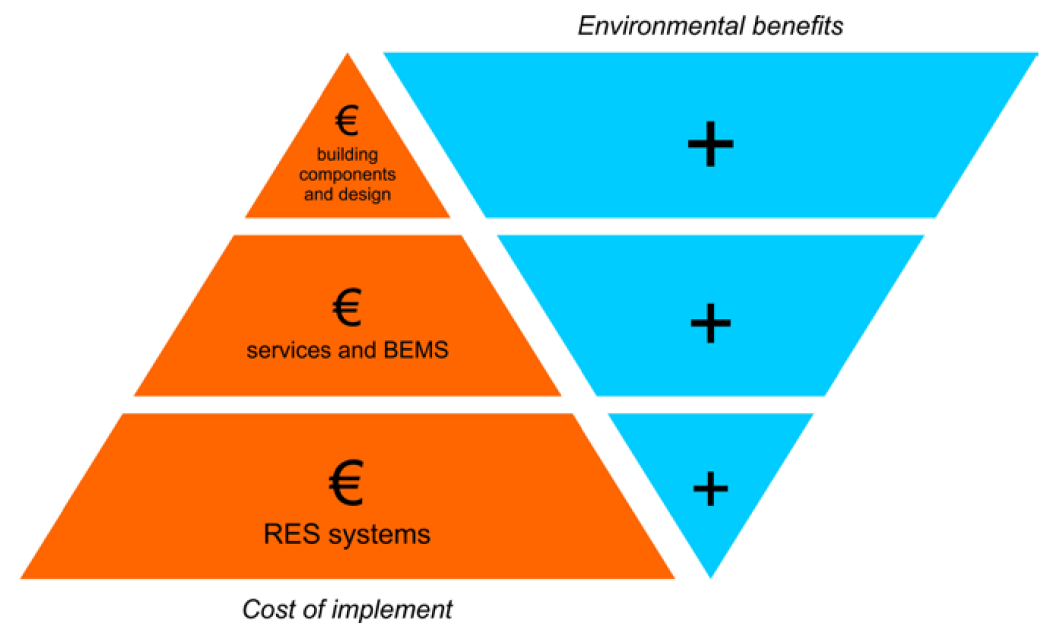

Figure 12. Intervention cost versus environmental benefits.

In Romania, the insufficient thermal insulation of the existing buildings compared to the requirements stipulated in the current thermal regulations is added to the limited seismic resistance of some structural types, as well as a state of degradation of the built part or an advanced wear of the installations. Therefore, many of the buildings requiring energy rehabilitation also need the assessment of the structural resistance and of strengthening scenarios.

The implementation of the Energy Performance Building Directive (2002/91/CE followed by the recast version 2010/31/UE) in Romania, has determined an upgrading of the minimum standards of energy performance of the buildings. It was introduced a methodology for energy balance calculation and an energy performance certificate, both for new and for existing buildings at their rehabilitation moment (Figure 13). Special norms for the inspection of the heating, cooling and ventilation devices 
were elaborated. Several successive National Programs for the rehabilitation/modernization of the multi-story residential buildings were applied in the last decades. Currently, the attention is directed to public buildings rehabilitation and certification.
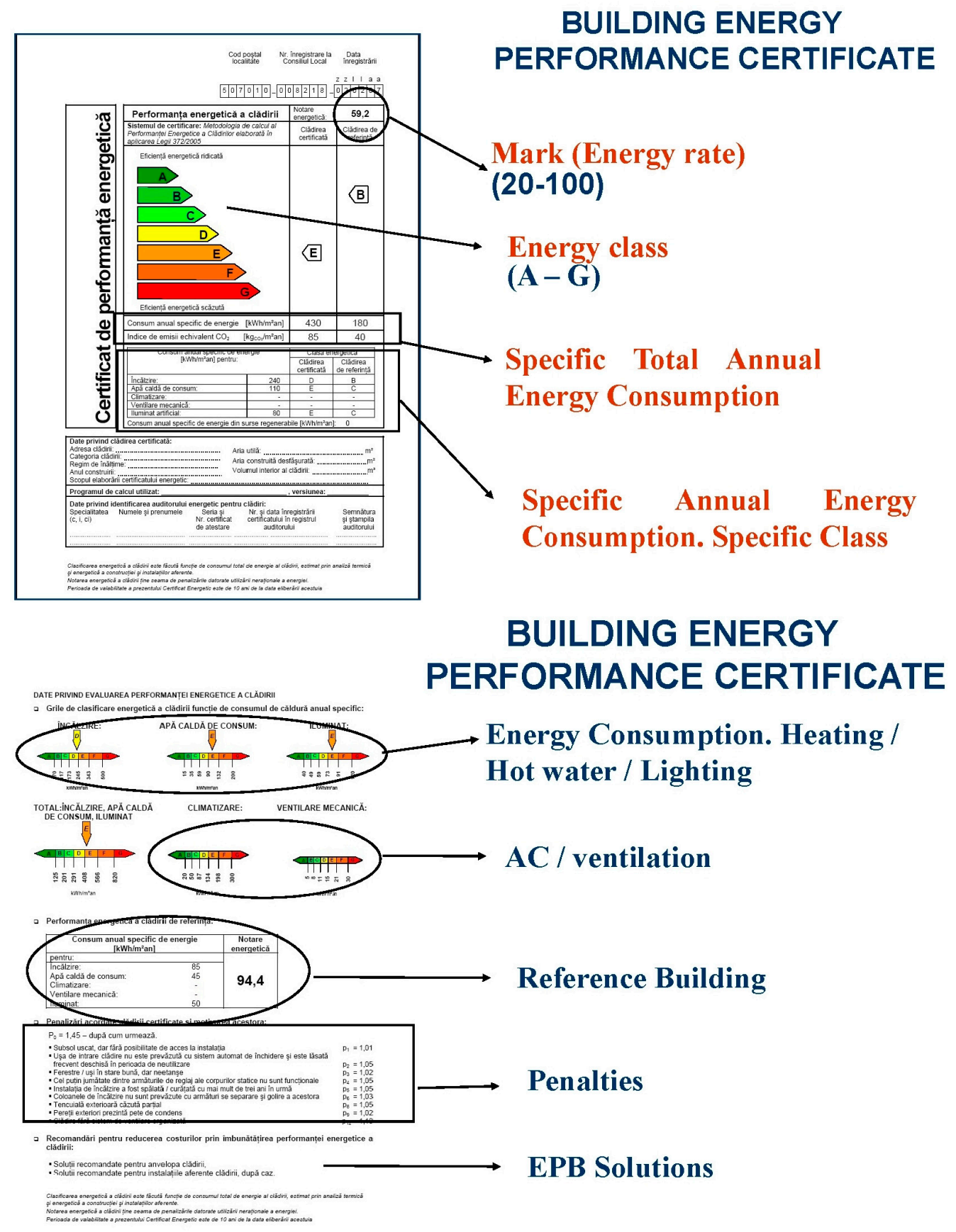

Figure 13. Content of the Romanian Building Energy Performance Certificate [42].

As for the building envelope (opaque components and fenestration), till now, it was applied additional thermal insulation layers using polystyrene or mineral wool plates with thermal conductivity $(\lambda)$ between 0.030 and $0.045 \mathrm{~W} / \mathrm{mK}$ (on external walls, roofs, ground slab), in many apartment blocks built during 1950-1990. Maximal values of the thermal transmittance U, for external walls, were $\mathrm{U}^{\prime}=0.70 \mathrm{~W} / \mathrm{m}^{2} \mathrm{~K}$ till 2010 and then $\mathrm{U}^{\prime}=0.55 \mathrm{~W} / \mathrm{m}^{2} \mathrm{~K}$, taking into account the effect of thermal bridges for each envelope element. 
The old types of windows (with wood frames and double glass without any coating) were replaced, in retrofitting programs, with high efficiency double glazing windows with low emissivity coatings, tinted and/or gas filled, having especially PVC frames $\left(\mathrm{U}=2 \mathrm{~W} / \mathrm{m}^{2} \mathrm{~K}\right.$ till 2010 and since $\left.2011 \mathrm{U}=1.3 \mathrm{~W} / \mathrm{m}^{2} \mathrm{~K}\right)$. In the last $2-3$ windows with triple glazing and low emissivity coatings are provided, having $\mathrm{U}=1.1 \mathrm{~W} / \mathrm{m}^{2} \mathrm{~K}$. In general, thermal bridges are taken into account in the calculations and in designing the renovation measures. However, sensitive connections remain with high values of the thermal bridge coefficient, in particular remaining penetration of RC elements in the insulation layer at basement or building foundation and installation of insulating windows in the structural layer (rather than in line with the insulation layer).

With the implementation of the first projects under the National Rehabilitation Program of the Housing Blocks-Condominiums, coordinated and funded by MDRAPFE and the Local Councils of City Halls, a number of new issues emerged.

The choice of technical and architectural solutions to improve the thermal performance of vertical envelopes must be done, in the future, using the optimal cost method and taking into account and controlling all important aspects.

The new approaches, which can be effectively adopted both in Italy and in Romania, are indicated in the following list:

- Ventilated facades (opaque ventilated façades, double skin glass façades, hybrid façades—wall/glass) were provided only for special buildings (offices, hospitals, public buildings, etc.) due to their initial high cost. The curtain walls using special glass were used for office buildings.

- Green walls and green roofs were used sometimes. Solar shading devices-external or internal, were provided without a detailed analysis. Passive solar energy systems like solar greenhouse were studied and provided in some cases.

- Active solar energy systems as PV panels, ST collectors and mixed systems were provided on some demonstration buildings but Building Integrated Photovoltaics (BIPV) in building envelopes are not usual, although used in pilot buildings.

Acoustic performance for the external thermal insulating systems is under study.

For roofs (flat or sloped), technologies to improve ventilation (single or double ventilation layers for sloped roofs), passive cooling (cool roofs), thermal inertia and waterproof (green roofs or cool roofs), RES use, etc., must be provided.

In Figures 14 and 15 some of the main solutions for thermal energy renovation are presented. The legend is common for the 3 figures and the relative numbers indicate: 1-external wall, possibly plastered; 2-efficient thermal insulation layer (EPS, mineral wool, etc.); 3-insulation protection layer (mineral additives mortar, with fibre glass reinforcement); 4-thin external finishing; 5-protective layer against wind; 6-ventilated layer; 7 - external cladding with closed joints; 8-damp-proof course; 9 -interior gypsum boards/dry plastering.
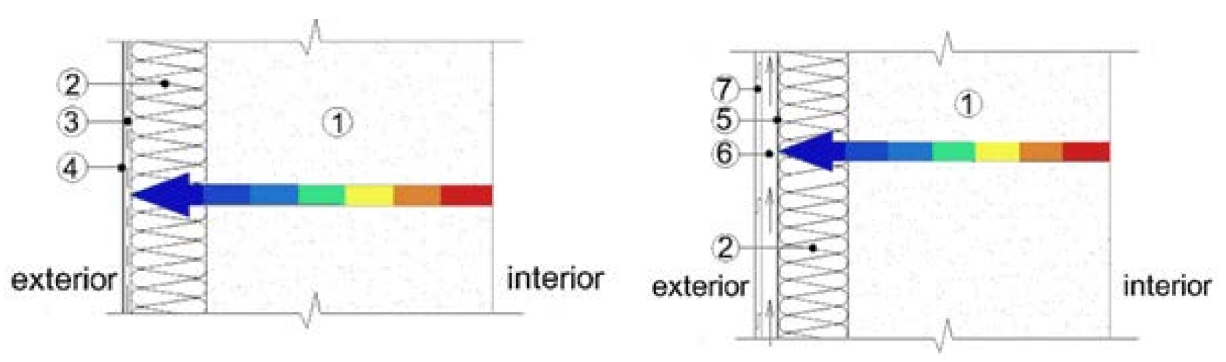

Figure 14. Main solutions for thermal energy renovation of external walls in current field, with external insulation. Left: External Thermal Insulation Composite System (ETICS) composite compact structure with protection layer of thin rendering with fiberglass reinforcement. Right: ventilated layer structure with protection layer and external cladding fixed trough a metallic frame [39]. 


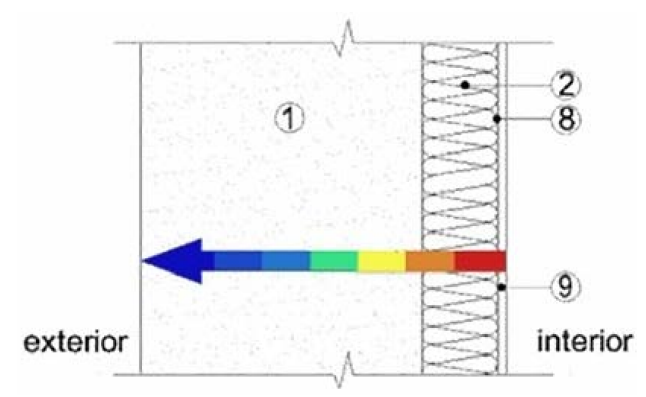

Figure 15. Main solutions for thermal energy renovation of external walls in current field, with internal insulation and finishing of gypsum boards [39].

For the future buildings (nZEB), the most promising and interesting insulating materials are: Aerogel, PCM, Transparent Insulation Materials (TIM), Vacuum Insulating Panels (VIP), organic materials (cork, sheep-wool, etc.), high efficiency windows.

In Romania, the nZEB concept does not seem to be easily applicable yet, in particular in the case of the renovation of existing buildings [94]. Besides the required investments and optimal integration of the technologies suitable for the construction and/or renovation of buildings at nZEB level, one of the main barriers for this consists in the skills gaps experienced by the building sector.

Some projects [95-98] approach this barrier by developing a roadmap for construction workforce qualification to achieve the sustainable energy policy objectives set for Romania for 2020. Thanks to them, mechanisms to supporting the national implementation of large-scale and long-term qualification schemes for thermal insulation systems and high thermal performances windows installers are defined (Figure 16).

Aspects such as the arrangement of the ventilation of the spaces in order to obtain adequate indoor air quality, the repair of the sidewalks, the removal of moisture and mould, the rehabilitation of the waterproofing, the modernization of the balconies and loggias were subsequently explicitly included in the current legislation. The arrangement of extensions and mansard spaces is of interest to a number of investors. The approach aims to provide RES, in order to achieve the cost-optimal energy performance of a building or, rather, of a district of buildings and also the highest indoor comfort by a good thermal insulation, restricting the heating load, the use of air conditioning units and artificial lights.

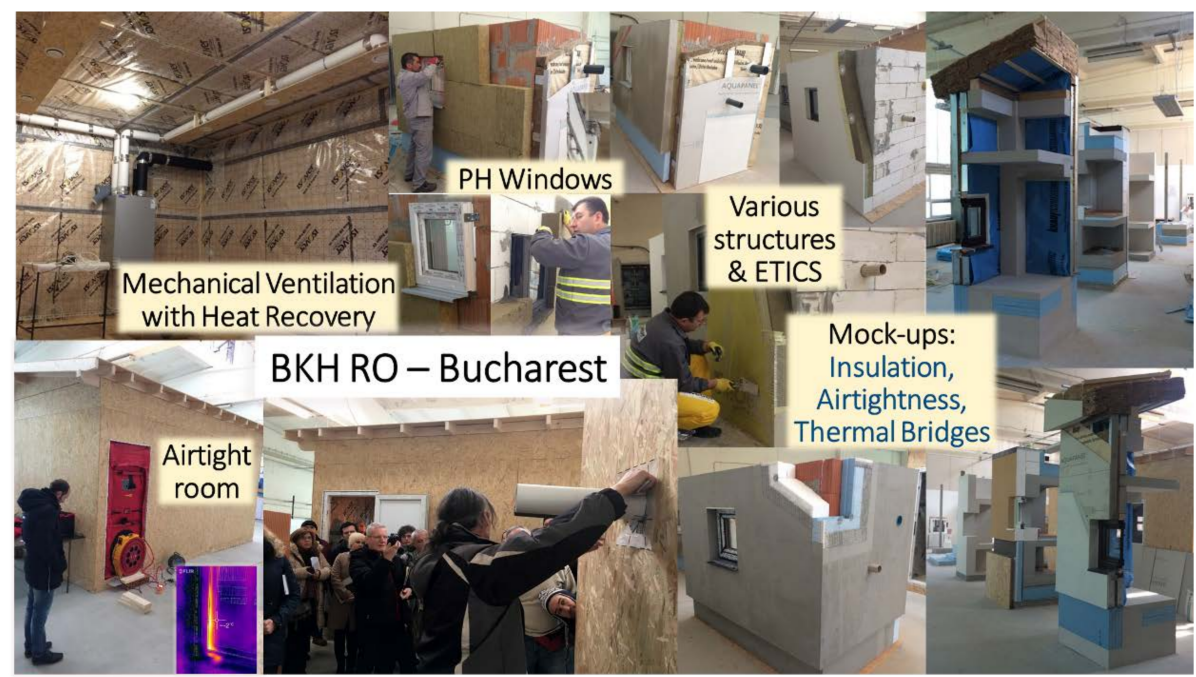

Figure 16. Practical training facility for nearly Zero Energy Building (nZEB) in the Building Knowledge Hub (Bucharest). 


\subsection{Common Practice and Current Projects of Energy Renovation in Romania}

The compound Prietenia of Sfantu Gheorghe City, consisting of 18 apartment buildings of five stories made of large panels, with 410 apartments, was under energy renovation from 2008 to 2009 (Figures 17-20). The project was done with the consultancy of UAUIM and IPCT Instalatii, in an integrated approach, to address also the architectural and landscape image as local urban issues.

The Prietenia Project allowed an energy reduction of ca. $60 \%$ and for this goal the following solutions and technologies have been applied:

- for terrace-EPS 120 of $16 \mathrm{~cm}$ thickness;

- $\quad$ for external walls-EPS 80 of $10 \mathrm{~cm}$ thickness (XPS $8 \mathrm{~cm}$ at socle);

- $\quad$ for slab over basement-EPS 70 of $8 \mathrm{~cm}$ thickness;

- $\quad$ for internal walls and slabs of entrance hall EPS 80 of $10 \mathrm{~cm}$ thickness;

- $\quad$ thermostatic valves and mixing water faucets, with reduced consumption.
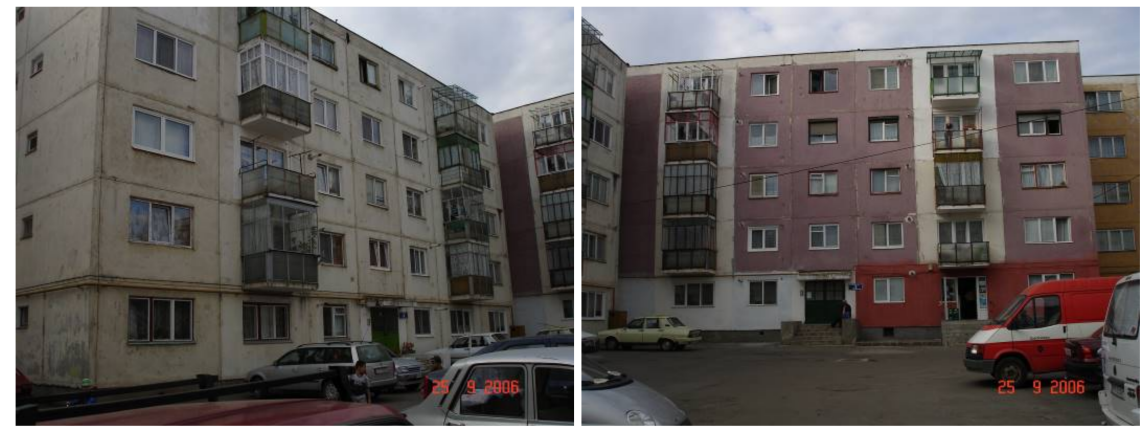

Figure 17. The apartment buildings before renovation, Prietenia compound, Sfantu Gheorghe.

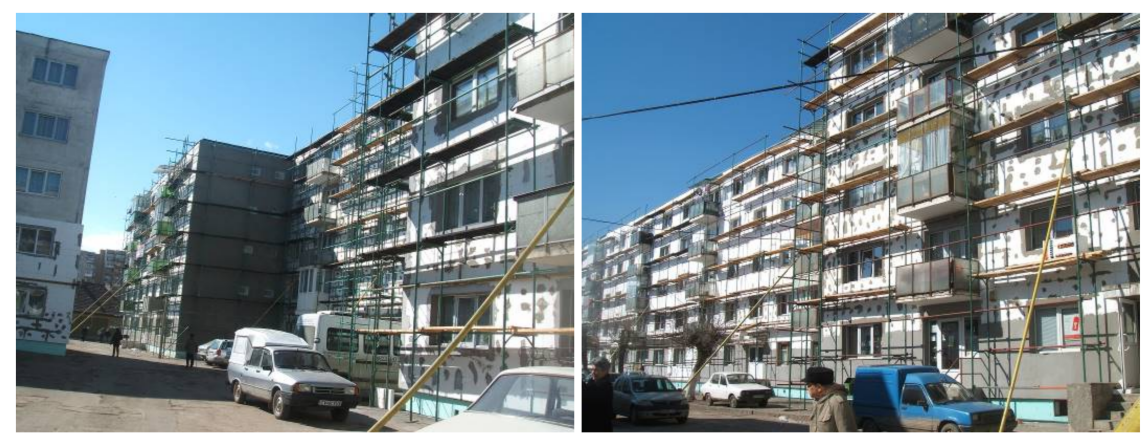

Figure 18. The apartment buildings under renovation, Prietenia compound, Sfantu Gheorghe.

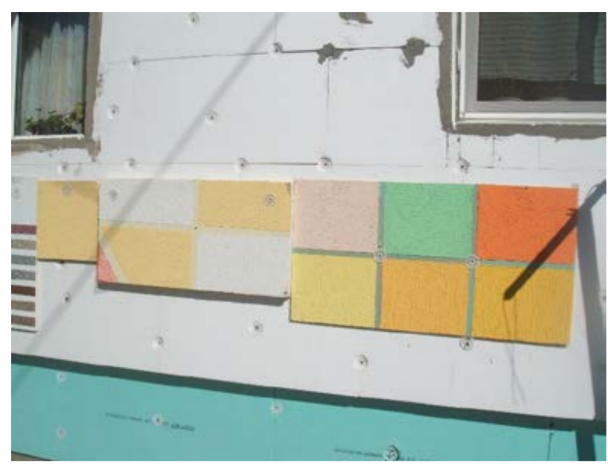

Figure 19. The apartment buildings under renovation, Prietenia compound, Sfantu Gheorghe. Community members were able to choose the colours of renovated facades. 

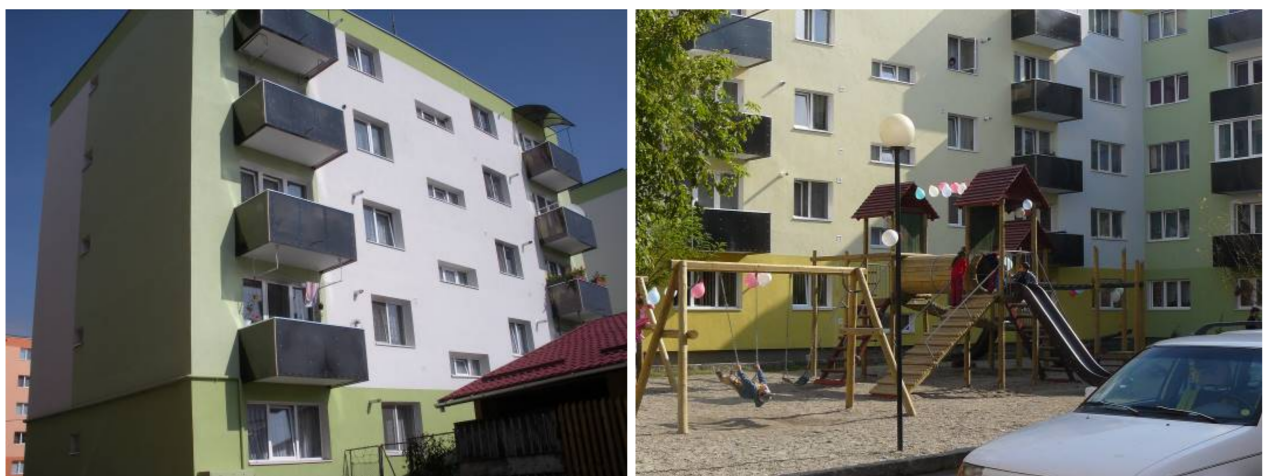

Figure 20. The apartment buildings and adjacent spaces, including playing grounds for children, at the end of renovation, Prietenia compound, Sfantu Gheorghe.

The mass renovation programs in Bucharest (Figures 21-24) and other large cities were quite successful and popular in the view of communities, especially because and when the cost was fully supported by local authorities or from European funds. However, from the point of view of architectural and technical quality the high speed of works and the lack of workers training caused some critics.
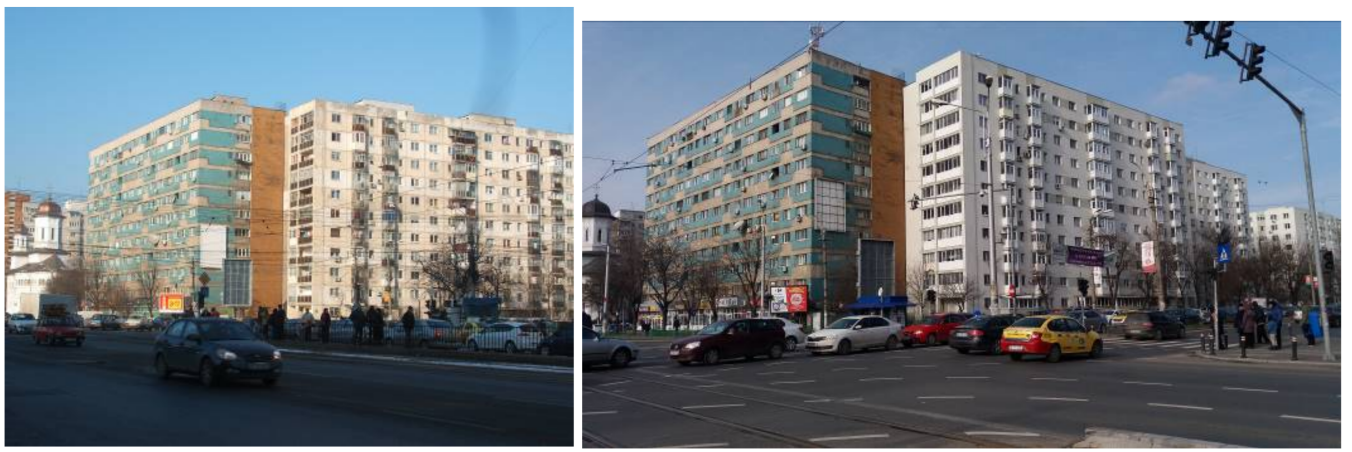

Figure 21. Large high-rise apartment buildings in Bucharest, erected in the 1970s, before and after energy renovation.

It is worth to mention that the shear wall structural types of 1970s, although designed to forces lower than current code, behaved satisfactorily in 1977 earthquake and thus they were included in energy renovation projects without other structural upgrading.
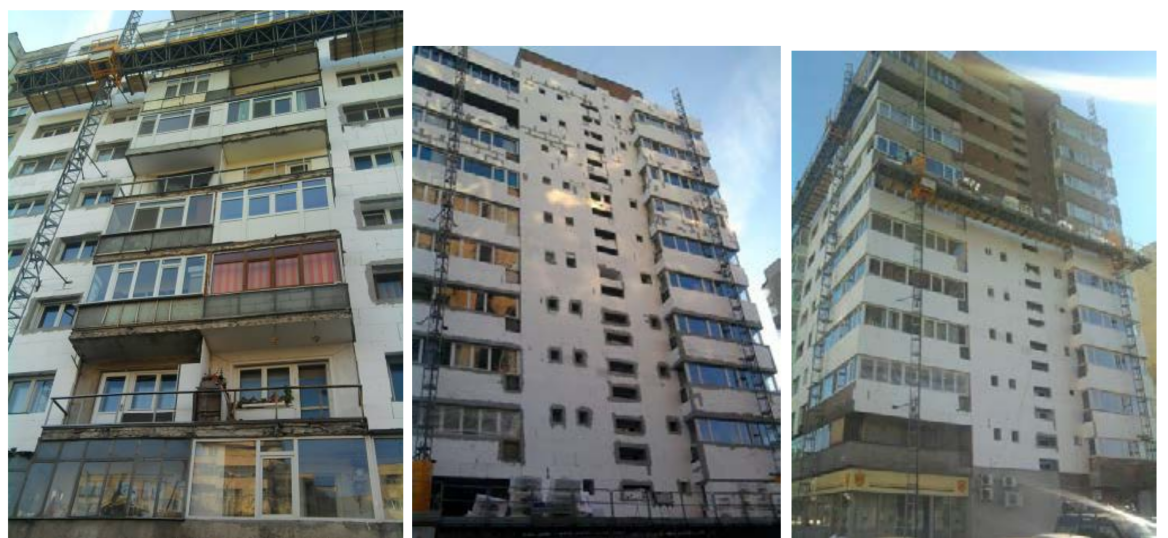

Figure 22. Large high-rise apartment building in Bucharest, erected in the 1970s, during energy renovation. 

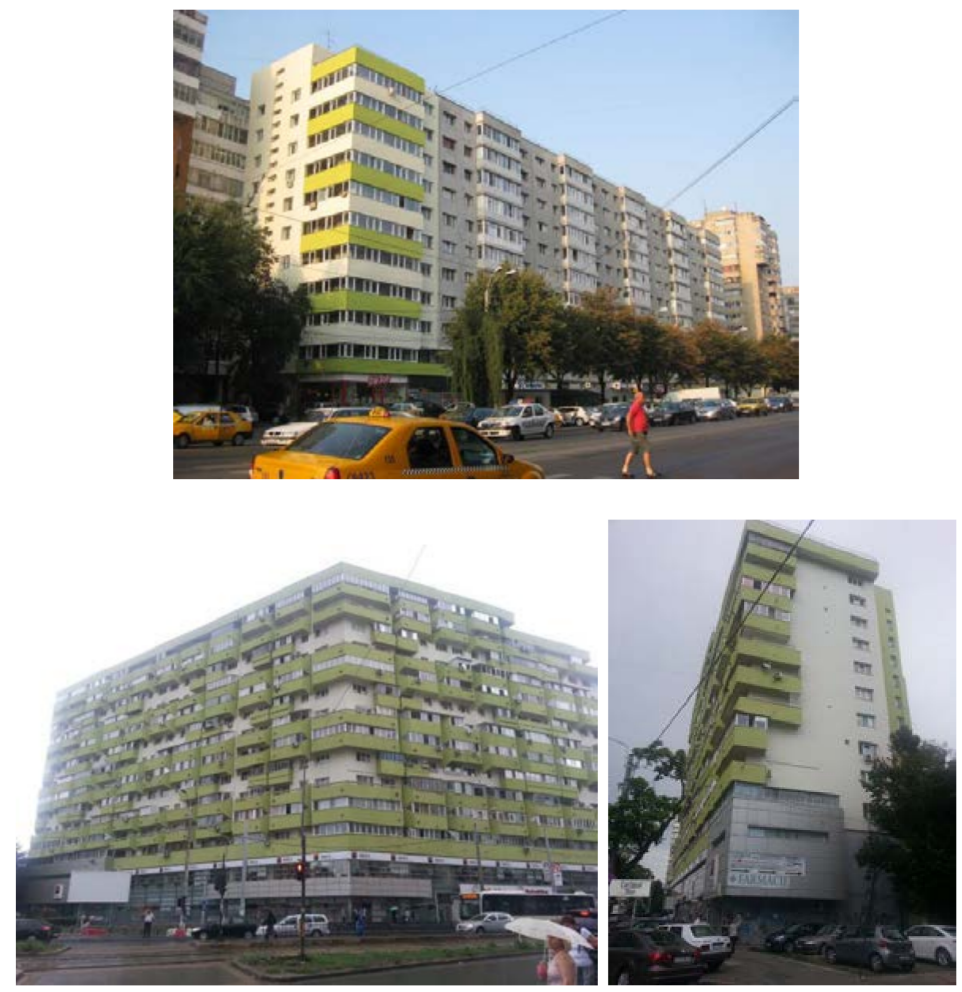

Figure 23. Large high-rise apartment building in Bucharest, erected in the 1970s, after energy renovation.

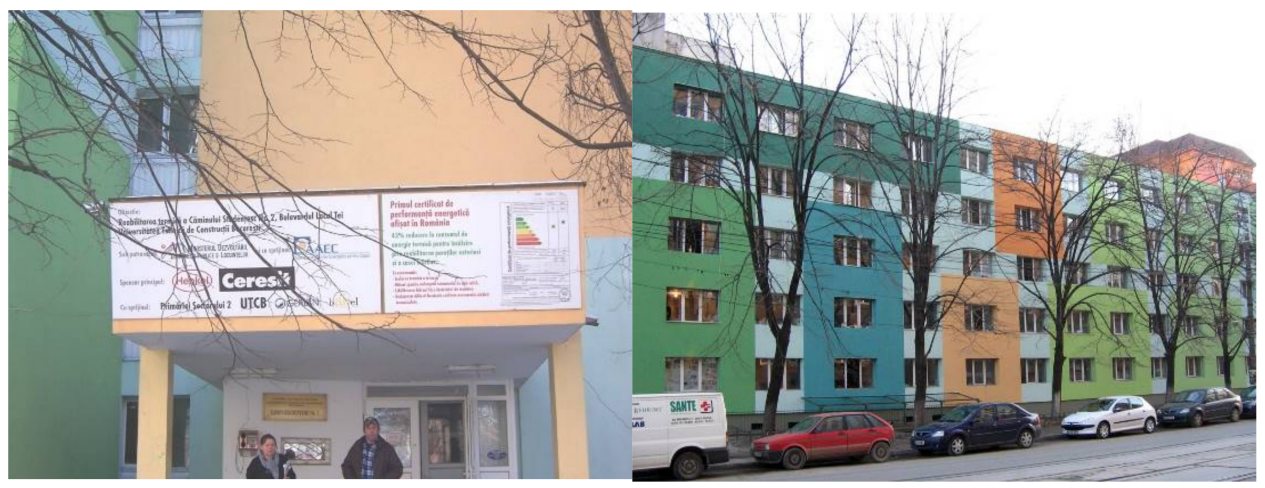

Figure 24. The UTCB Lacul Tei Students Dormitory building after energy renovation (2007). The first public building with displayed Energy Performance Certificate.

The IR images presented in Figure 25 illustrate the qualitative impact of applying external insulation to the Students Dormitory building, while the previously replaced windows (double glazing aluminium profile, moderate thermal performance) were not improved in the energy renovation. 

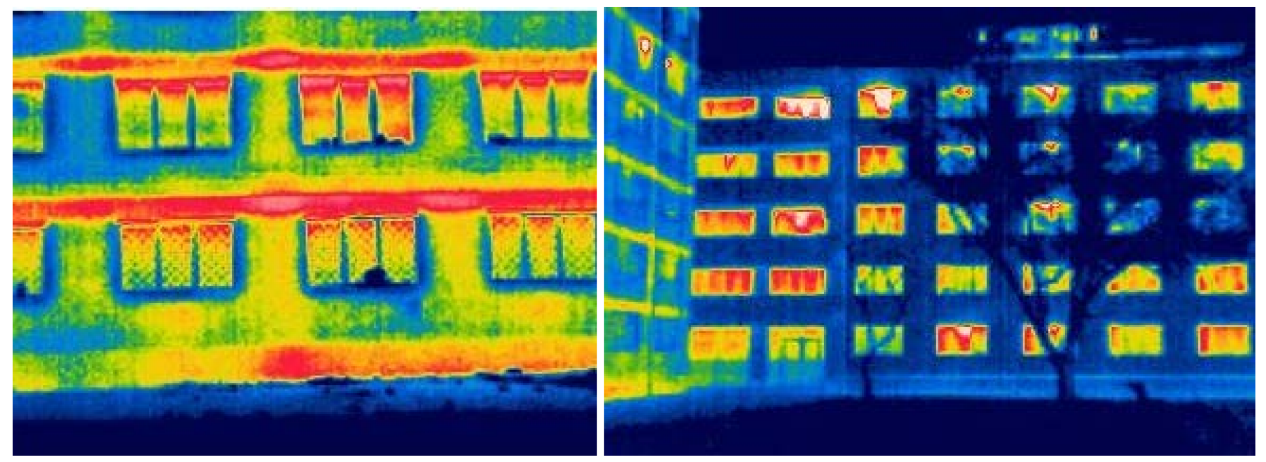

Figure 25. The UTCB Lacul Tei Students Dormitory building. IR thermography images before and after energy renovation (2007).

Based on the JRC study, Romania has one of the 10 exemplary Renovation Strategies (as required art. 4 of the Directive 2012/27/EU), ranked the 3rd at EU level, mainly for having detailed estimations, 4 scenarios, multiple benefits assessed, cost benefit analysis. The biggest source of funding for energy efficiency comes from EU Cohesion Policy Funds, while between 2014 and 2020, Romania intends to allocate more than $€ 1.25$ billion to building renovation of residential and public building. The majority of the funds will be used as grants for the building owner/association, covering (some of) the cost of the thermal renovations. However, deep renovations rate remains among the lowest in Europe, while the energy renovation of individual houses is not effectively supported by public funding nor stimulated by actual incentives. Moreover, the energy performance level of current deep renovation is far from the nZEB levels both in terms of design specifications and performance of works (limited insulation, attention to thermal bridges, no mandatory airtightness levels or mechanical ventilation with heat recovery, etc.). Nevertheless, minimum requirements in terms of maximum primary energy use for space heating are in force for major renovation of existing buildings since 2017. One could envisage that this is a first step towards building renovation at nZEB levels in Romania, still regulation has to be improved, nZEB technology market growth has to be stimulated and private investments have to be attracted by innovative and sustained communication campaign along the public funding energy renovation programs applied for demonstration buildings.

\subsection{Common Practice and Current Projects of Energy Renovation in Italy}

The requalification of the multi-storey RC buildings is one of the hardest achievement [99]. Recently, a specific research study has verified the possibility to transform this kind of buildings into nZEB, with special attention to the Southern regions of the country [100]. The target of this study was also to contain the Pay Back Time (PBT). To get these aims, the authors have defined the most economical way to insulate the whole building envelope and to integrate PV panels in the façades. The simulations were carried on two multi-storey building of Librino, a popular neighbourhood of Catania, designed in the Seventies by Japanese architect Kenzo Tange [101].

In the first case study (Figure 26), the design actions have been limited, in order to contain the PBT in around 10 years (taking advantage of the current fiscal incentives). The U-value of the envelope has been reduced by applying an external insulation (Table 7). The installation of a new electrically powered air-water reversible heat pump has been considered for heating and cooling purposes. The calculation of the primary energy balance before and after renovation has shown a reduction of 37.1\% (Table 8). Copper Indium Gallium Selenide (CIGS) PV panels integrated in the façades will be responsible for the electricity production onsite (Figure 26). In particular, in spring and fall the electricity production exceeds the electricity demand (Figure 27); in winter, external electricity contributions are limited, while in summer the electricity demand turns out to be higher than the electricity production. 

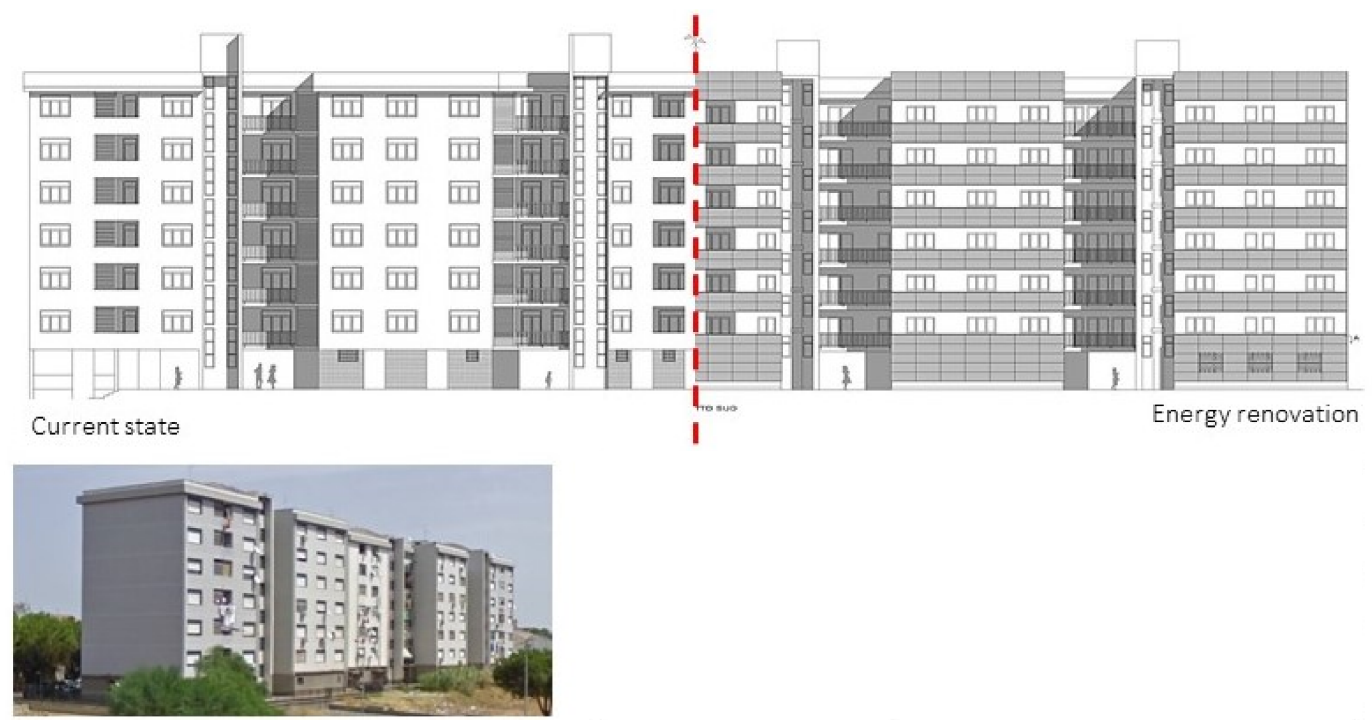

Figure 26. Energy renovation of an apartment block in Librino-Catania [100].

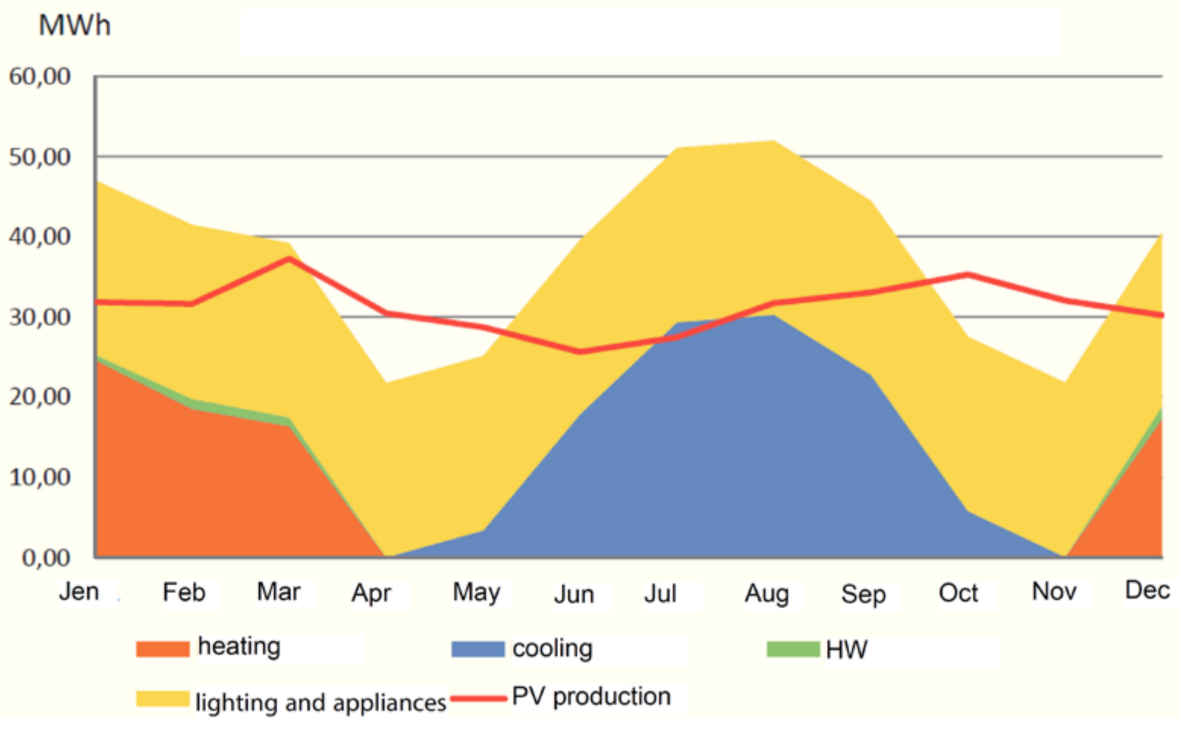

Figure 27. Comparison between electricity production from photovoltaic (PV) and electricity consumption [100].

Table 7. U-value of the building envelope before and after renovation.

\begin{tabular}{|c|c|c|}
\hline \multirow{2}{*}{ Building Component } & Before & After \\
\hline & \multicolumn{2}{|c|}{$\left[\mathrm{W} / \mathrm{m}^{2} \mathrm{~K}\right]$} \\
\hline External walls (RC) & 1.71 & 0.35 \\
\hline External walls (clay bricks) & 0.51 & 0.23 \\
\hline Roof & 0.44 & 0.44 \\
\hline Slab over the porch & 0.90 & 0.46 \\
\hline Ground slab & 2.09 & 0.37 \\
\hline
\end{tabular}


Table 8. Primary energy balance before and after renovation (without renewables) ( $\mathrm{H}=$ heating, $\mathrm{C}=$ cooling, $\mathrm{W}=\mathrm{DHW}, \mathrm{L}=$ lighting.

\begin{tabular}{cccccc}
\hline$\left[\mathbf{k W h} / \mathbf{m}^{2} \mathbf{a}\right]$ & $\mathbf{P E}_{\mathbf{H}}$ & $\mathrm{PE}_{\mathbf{C}}$ & $\mathbf{P E}_{\mathbf{W}}$ & $\mathbf{P E}_{\mathbf{L}}$ & $\mathbf{P E}$ \\
\hline Before & 61.99 & 15.43 & 20.27 & 75.36 & 173.05 \\
After & 38.31 & 10.27 & 0.00 & 60.29 & 108.87 \\
\hline Reduction & $38.2 \%$ & $33.4 \%$ & $100.0 \%$ & $20.0 \%$ & $37.1 \%$ \\
\hline
\end{tabular}

In the second case study, Cadmium Telluride (CdTe) PV panels were specifically dimensioned to get the nZEB standard, covering large part of the façade (more than $60 \%$, excluding the northern side). In this case the energy renovation becomes also an opportunity to redesign the façades (Figure 28), changing the building architectural image. The energy demand has been reduced by insulating the whole envelope from the outside and by providing an air-water reversible heat pump. Table 9 shows the improvement of the thermal insulation of the building envelope after the proposed intervention. According to the calculation of the primary energy balance before and after renovation (Table 10), the primary energy needs decrease by $62 \%$. The PBT turned out to be 9 years (with fiscal incentives).
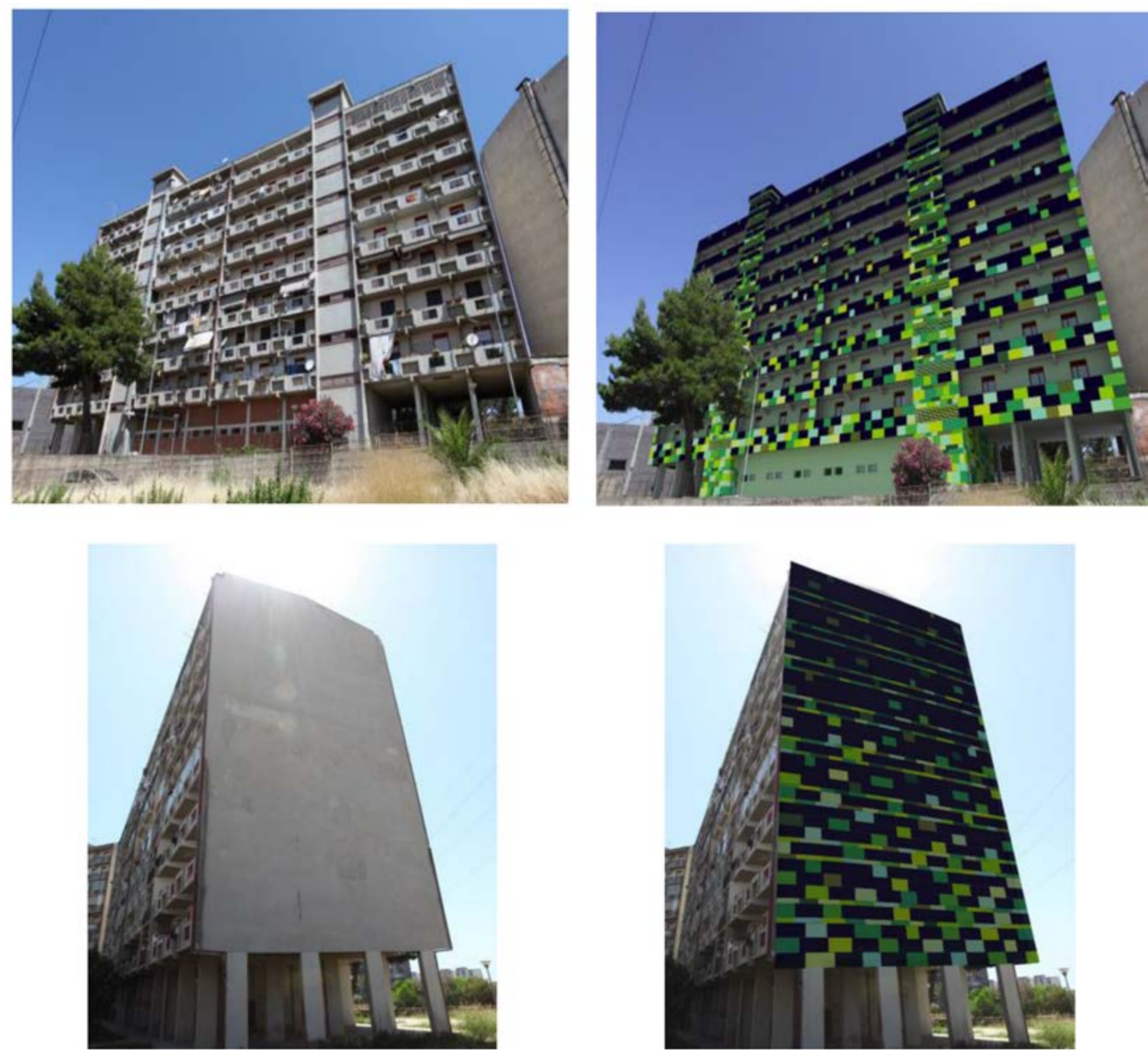

Figure 28. Comparison between the PV energy production and energy consumptions [100]. 
Table 9. U-value of the building envelope before and after renovation.

\begin{tabular}{|c|c|c|}
\hline \multirow{2}{*}{ Building Component } & Before & After \\
\hline & \multicolumn{2}{|c|}{$\left[\mathrm{W} / \mathbf{m}^{2} \mathbf{K}\right]$} \\
\hline External walls (RC) & 4.10 & 0.40 \\
\hline $\begin{array}{l}\text { External walls (lightweight } \\
\text { concrete) }\end{array}$ & 1.96 & 0,39 \\
\hline Windows & 5.80 & 1.60 \\
\hline Roof & 3.85 & 0.30 \\
\hline Slab over the porch & 3.14 & 0.38 \\
\hline
\end{tabular}

Table 10. Primary energy balance before and after renovation without renewables) $(\mathrm{H}=$ heating, $\mathrm{C}=$ cooling, $\mathrm{W}=\mathrm{DHW}, \mathrm{L}=$ lighting).

\begin{tabular}{cccccc}
\hline$\left[\mathbf{k W h} / \mathbf{m}^{2} \mathbf{a}\right]$ & $\mathbf{P E}_{\mathbf{H}}$ & $\mathbf{P E}_{\mathbf{C}}$ & $\mathbf{P E}_{\mathbf{W}}$ & $\mathbf{P E}_{\mathbf{L}}$ & $\mathbf{P E}$ \\
\hline Before & 153.42 & 15.13 & 19.26 & 66.85 & 256.46 \\
After & 20.79 & 21.78 & 0.00 & 54.92 & 97.49 \\
\hline Reduction & $86.4 \%$ & $-43.9 \%$ & $100.0 \%$ & $20.0 \%$ & $62.0 \%$ \\
\hline
\end{tabular}

The exploitation of the façades for PV installation turned out to be essential, since the roof surface of apartment blocks with more than 4 stories is generally insufficient to host all the panels required to reach the nZEB standard.

\section{Seismic versus Energy Renovation: Technical Solutions, between Opportunities and Constraints}

In Italy and Romania, a large number of RC structures need seismic strengthening. While for some recent generations the base isolation and bracing is possible and feasible, for most of cases a considerable amount of new structural members is required. Many traditional techniques are available and provisions that regulate their use are given in the relevant parts of the Italian [12-14], Romanian [35] and European [15] codes. Some examples of possible solutions are presented below, along with comments on their implications on the energy renovation solutions.

Figure 29 shows the strengthening of columns by concrete jackets. The concrete cover added to most of columns involves also the cutting and/or removal of some envelope material. The final design must take into account the adequate detailing and calculation in order to ensure a continuous thermal insulation for control of thermal bridges impact on performances.

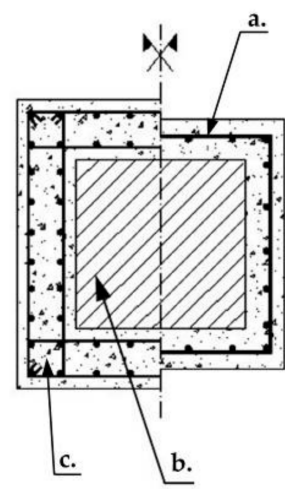

Legend

a. r.c. jacketing with stirrups only for shear force capacity

b. existing columns

c. jacketing to increase overall capacity

Figure 29. Strengthening solution for existing columns, using concrete jacketing (adapted after [34]).

In Figure 30 the new shear wall, when and if it is added at exterior, will change completely the envelope thermal parameters therefore the energy renovation design shall take into account the new details and thermal transmittance values. In Figures 31 and 32 the jacketing of shear walls is necessary 
on the edges. In case of external walls, the need of special care for energy renovation detailing may be limited to those areas.

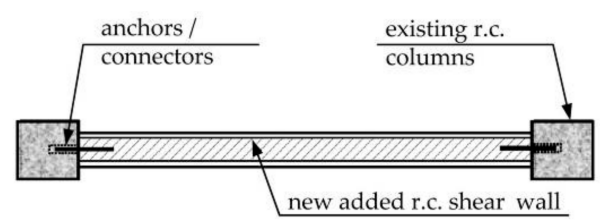

Figure 30. Strengthening solution using new structural walls, as shear walls (adapted after [34]).

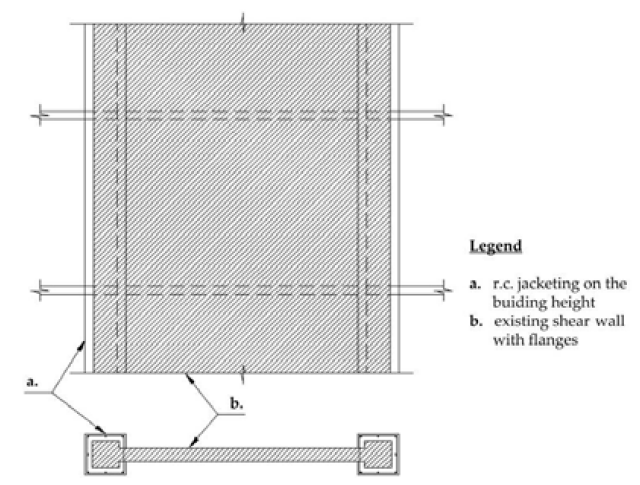

Figure 31. Strengthening solution for structural walls, with RC jacketing interventions on the edges (adapted after [34]).

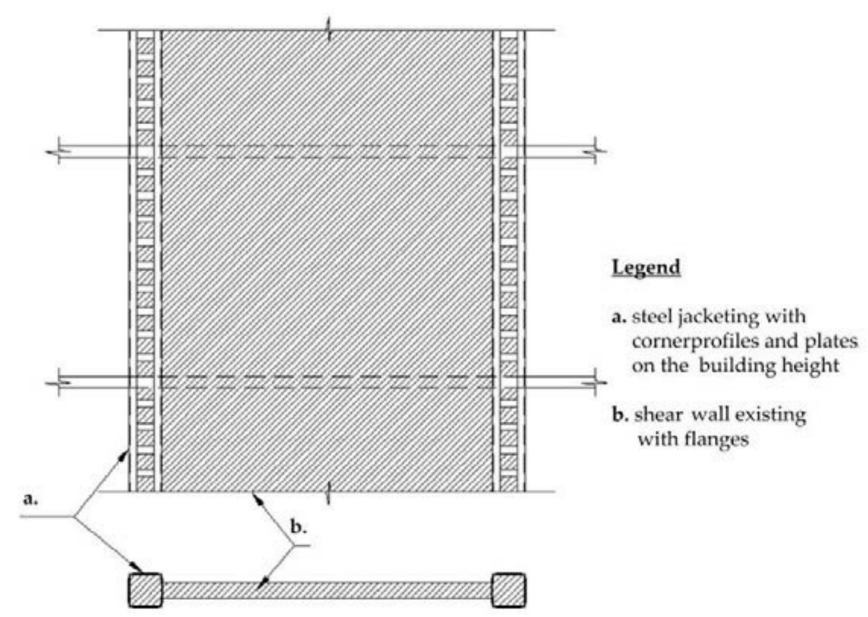

Figure 32. Strengthening solution for structural walls, with steel jacketing interventions on the edges (adapted after [34]).

However, when looking in details of such solutions, as in Figure 33, the building of a new and greater flange-column of a shear wall also changes the envelope situation, with the need of careful thermal bridges analysis. In Figure 34, the renovation with steel elements is much easier to apply but steel has a greater heat transfer capacity and also changes the envelope situation, with the need of careful thermal bridges analysis. 


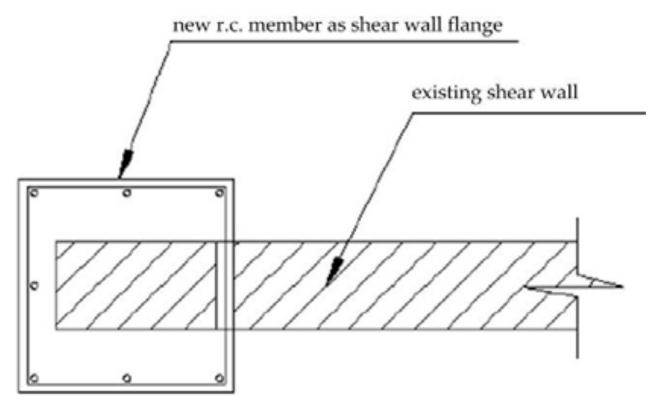

Figure 33. Detail of strengthening solution for structural walls, with RC jacketing interventions on the edges (adapted after [34]).

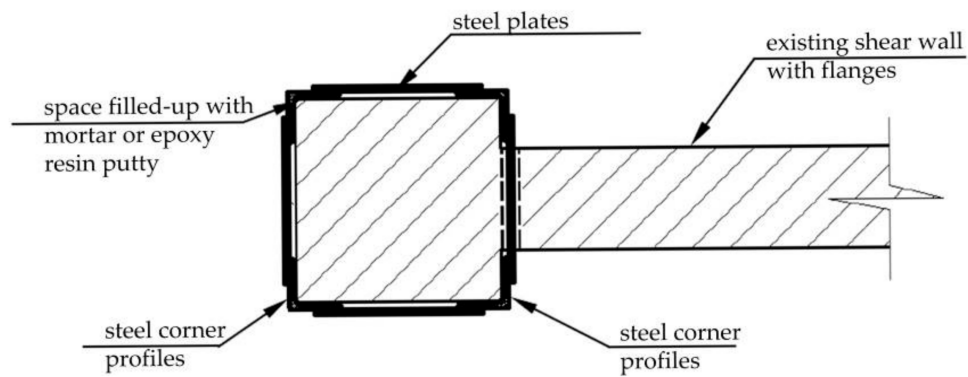

Figure 34. Detail of strengthening solution for structural walls, with steel jacketing interventions on the edges (adapted after [34]).

The examples herein presented point out that many solutions are available in literature to upgrade existing structures by enhancing its stiffness, strength and ductility capacity. However, these interventions may have a negative impact on the thermal performance of the building, thus requiring additional measures. On the other hand, any intervention devoted only to the energy requalification of RC buildings could be nullified by the effect of the earthquake if the building is not seismic-resistant. The interventions depicted in the previous figures (Figures 29-34) are intended to add lacking properties, in terms of resistance and ductility, to structural members in existing buildings. The cases referred to shall ensure such qualities by adding stronger or more ductile flanges to shear-walls, of inserting a web between columns, as to become structural ones. They shall be associated with other reinforcement measures. Based on this consideration, existing buildings should always be assessed in terms of both seismic and energy deficiencies and the new challenge will be to ideate, design and realize interventions that integrate seismic upgrading and energy renovation. An example that fits well this philosophy is the intervention by Takeuchi et al. $[102,103]$ on the Midorigaoka-1st building of Tokyo Institute of Technology, a 6-story RC building designed in 1966 before the revision of Building Code of Japan in 1971. The main deficiency of the structure was the low ductility capacity of the columns. Furthermore, the thermal performance of the building envelope did not satisfy the current standard in Japan. The solution proposed by Takeuchi et al. is an integrated facade that includes glasses, louvers and a steel BRB frame (Figure 35). This multi-skin exoskeleton improves both the seismic and the thermal performance of the building. In particular, the steel frame equipped with BRBs is firmly attached to the ground and to the building façade. In occurrence of ground motions, the BRBs act as hysteretic dampers, yield and absorb input seismic energy before that the RC structure is damaged, thus reducing the drifts and protecting the structure. The system of glasses and louvers properly oriented can mitigate the inner temperature both in summer and winter and reduce the consumption of energy needed for heating and refreshing, respectively. 


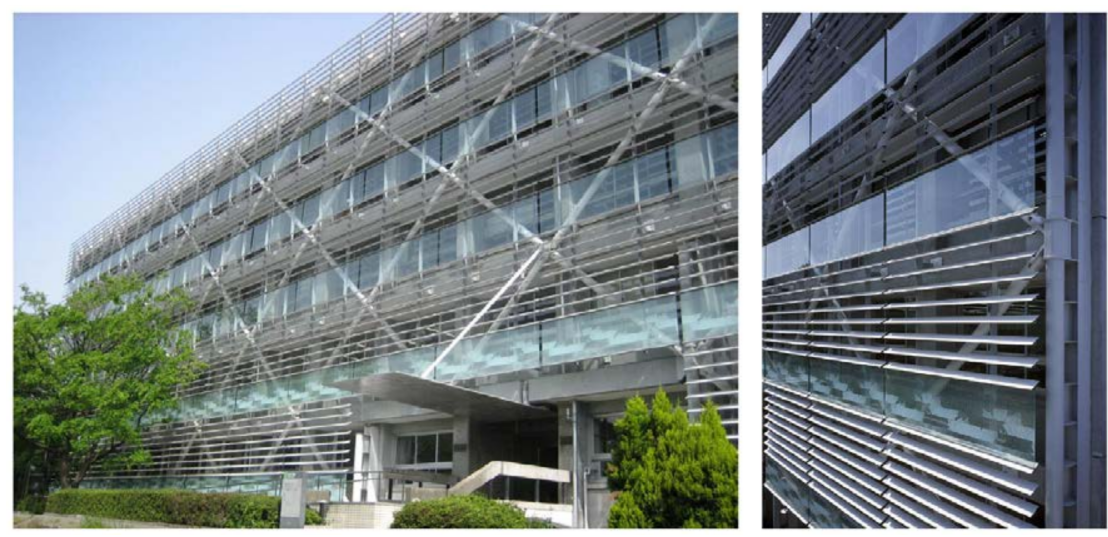

Figure 35. Midorigaoka-1st building after retrofit [103] (photographs by Mamoru Ishiguro).

There are also some recent and interesting research works that propose and/or assess combined seismic ad energy renovation scenarios for recent buildings. For instance, Leone and Zuccaro [104] have developed, within the EU-FP7 CRISMA project, a multi-criteria decision support system to select the optimal integrated retrofitting scenario, taking into account technical, financial and economic aspects. The proposed tool aims at enabling decision makers and local authorities to implement policies and large-scale programs devoted to the sustainable improvement of the existing residential stock. Calvi et al. [105] have proposed a "green and resilient indicator" to evaluate the earthquake resilience and energy efficiency of the exiting building stock. Manfredi and Masi [106] have proposed an integrated retrofitting intervention that consists in replacing the existing masonry infill walls with hollow clay blocks that are able to increase both seismic and thermal performance. For mid-low hazard areas, this technique could determine a full rehabilitation with regards to both seismic and thermal requirements, in compliance with the corresponding codes. La Greca and Margani [19] have highlighted the advantages of combined renovation actions, indicating the barriers that currently limit such actions and suggesting possible countermeasures. Moreover, the H2020 ProGETone project [107] is currently developing retrofitting solutions based on the implementation of multi-skin exoskeletons to enhance the seismic resilience and the energy performance.

\section{Discussion}

The seismic and energy renovation combined approach has strong and weak points, both in Italy and in Romania.

The recent Italian legislative has introduced different incentives, in form of tax credit (so-called 'SismaBonus'), which, especially from 2017, considerably reduce the economic investment for the renovation of earthquake-prone buildings. In particular, the building owners in seismic areas may receive a tax credit distributed over 5 years that covers up to $85 \%$ of the cost of the retrofit intervention, with a cost limit of $€ 96,000$ per apartment. Simple guidelines are provided to assess the seismic risk class of buildings in compliance with the current seismic technical code for constructions. Hence, the amount of the tax deduction is related to the class increase due to the strengthening intervention.

In addition, in Italy also the energy efficient renovation benefits from different fiscal incentives, which since 1998 have considerably encouraged this kind of intervention. Nowadays, energy retrofitting investments take advantage of VAT reductions (10\% instead of $22 \%$ ) and tax credits that range from $36 \%$ to $75 \%$ of the renovation cost, with a limit of $€ 40,000$ per apartment (so-called 'EcoBonus'). In particular, interventions on single family houses benefit from fiscal incentives that allow to write off $36 \%$ of costs on taxes, with deductions equally distributed over 10 years. This share increases from $70 \%$ up to $75 \%$ for apartments buildings, according to the reached energy performance. If required, the tax credit can be assigned to third parties, such as construction companies. Alternatively, it is possible to benefit from incentives governed by the Ministerial Decree of 16 February 2016 (also known as 'Conto Termico 2.0') that 
provides subsidies for the production of thermal energy from RES and the increase in energy efficiency. These subsidies cover $40 \%$ of the eligible expenditure, with specific limits for the unit and total costs of each type of interventions. They will be refunded either in five annual rates or in a single solution in the case of public administrations or Energy Service Companies (ESCOs).

From January 2018 [108], it is also possible to benefit from tax credits that cover up to $85 \%$ of the cost for combined seismic and energy renovation actions of apartment blocks, with a limit of $€ 136,000$ per apartment and deductions distributed over 10 years (so-called 'SuperBonus').

The Italian residential real estate has a very high level of fragmentation. It is usually quite difficult to reach a consensus among the building owners for the implementation of renovation works.

In Romania, since 69\% of residential buildings existing in 2011 have been erected before 1977, many dwellings may have insufficient earthquake protection. The technical aspects of assessment, design and solutions for seismic strengthening are solved in relevant codes and laws starting during the1990s, while the energy rehabilitation has also a pertinent evolution, fully correlated with the EU Directives.

The problem of funding seismic strengthening is legally and financially solved since 1994 but the key issue is that of relationship between the funding provided by MDRAPFE and actual management of seismic strengthening projects which is done by local authorities. In Bucharest, there is a large list of pre-1940 buildings ranked at seismic risk but the number of buildings that were strengthened is relatively low.

Presently in Romania, is in force a yearly National Program for seismic risk reduction (based on Ordinance n. 20/1994) [81] correlated with Code P100-3/2008 [35] and EC8 provisions. For the time being, the National Program for thermal and energy rehabilitation [80] is a more successful social project, because it was applied on buildings with low or any seismic risk. The cost of energy rehabilitation was born in most cases by local authorities, from own budgets or European Programs.

In both countries, the main reason that makes the energy rehabilitation to be one step in front of structural interventions is that seismic strengthening involves the structure and is operated mainly from the inside of the building, while the energy renovation involves, above all, the envelope and is operated mostly from the outside. The energy renovation works are speedy, while for seismic strengthening owners are often afraid of high costs and related mortgaging; many of them are rather old and low-income, absentees or just do not want to de disturbed by evacuation and long-term noisy works. On the other hand, the funding is from separate sources and under separate legal framework, thus the full renovation approach is difficult.

From the energy renovation perspective, the level of ambition in terms of performance follows the nZEB target. Even if these performances are made mandatory only for new buildings authorized in very short time from now, the EU policies are rapidly advancing towards the renovation of existing building stock at nearly zero energy levels. This implicates a very high insulation level, high performance (and usually heavy) windows (installed in line with the applied insulation, that is, outside the mechanical resistance layer) and with minimized thermal bridges. This could be a very difficult task for the design of energy renovation technical solutions, especially in respect to the highly enforced design provisions due to the high seismic risk. In current practice, most of the building envelope renovation details (e.g., joining different building components) are designed with greater focus on mechanical resistance issues than heat transfer concept (e.g., avoiding thermal bridges), the result being usually an interrupted insulating envelope. In all cases, mechanical resistance has to be ensured but if penetration of the insulating layer is unavoidable, then the thermal conductivity of the penetrating material should be as low as possible and insulation layers at building component connections should merge into each other over the entire surface without interruption.

In this respect, best-practice guidelines and detailed specification for the building envelope have to be developed in order to support suitable solutions for nZEBs, tested in order to comply with the rigorous seismic design provisions. The aim is to inform and to shape the internal market in order to increase the current level of technical knowledge and technologies before the legal requirements under Directive 2010/31/EU cause a blockage of the local construction industry due to the inability to fulfil the Directive. 


\section{Conclusions}

The European and National Standards and Directives have been promoting, from different sustainability reasons, seismic and energy renovation actions to mitigate disasters and climate changes impact. In Italy, over 60\% of the current building stock was built between the 1950s and the 1980s, when seismic safety and energy efficiency regulations were absent or mandatory only in few regions. As a consequence, most of the real estate is earthquake-prone and highly energy-consuming [19]. The combined seismic and energy renovation of Italian buildings is of paramount importance for the safety of the population against earthquakes and other natural hazards related to climate change.

In Romania, there is a comprehensive framework of laws and technical regulations, both for earthquakes and energy, implemented over the last five decades for new and existing buildings. In this country, the wide impact of the 1940 and 1977 earthquake is a landmark, while the probability of a large earthquake in the near future is increasing, thus the seismic risk reduction is a national priority. The National Program for thermal and energy rehabilitation of buildings is a separate endeavour, also a priority, pushed by the impact of climate changes and the related European Union Directives. In order to achieve the ambitious and very demanding objectives of Eurocodes and European Energy Performance Directives, under Romanian laws, it is necessary to mobilize all the involved stakeholders, to identify and face the positive and negative aspects and barriers, as well as the deficiencies that exist or may occur in the future.

In both countries, the policy of renovation of the real estate is hindered especially by high costs and disruptions for users. The integration of structural, architectural and urban planning approaches may improve the effectiveness and diffusion of these actions. However, steps like structural analysis, energy audits, public tender procedures, quality of projects and execution, regulatory framework, financial and fiscal incentives, quality control, training of designers and builders and workers' qualification still represent critical issues.

A variety of techniques for seismic upgrading and energy renovation of buildings are already available. Some of these techniques are known to structural designers and construction companies for a long time now and provisions for their application are provided in the current technical regulations. Other techniques, which are classified as innovative, are also applicable because studies that demonstrate their effectiveness and the relevant design guidelines are available in the technical literature. However, each of these techniques aims at improving only one aspect of the building performance: reduction of the risk of damage/failure caused by earthquakes or reduction of the energy consumption during the building operation. Based on the framework depicted above, it emerges that often seismic upgrading interventions can have no effect or may be even detrimental on the energy performance of the building and vice versa. Hence, the main challenge of the next years is to develop approaches that integrate together techniques for energy and seismic renovation. Important aspect to be deepened are the study of the compatibility of the integrated techniques and the definition of interventions that improve both seismic energy performance. The target of these approach should be the transformation of the existing energy-consuming and seismic-prone buildings in nZEB seismic-resistant ones. The availability of such integrated approaches for seismic-energy upgrading can promote the renovation of existing buildings by pursuing multiple targets: (i) to benefit from fiscal and financial incentives for both seismic and energy renovation, (ii) to maximize the positive effect gained by the intervention on the building (two performance objectives are reached with a single intervention) and (iii) to preserve in time the value of the investment (the investment for energy renovation could be nullified by earthquakes if seismic upgrading has not been pursued too). To this purpose, the exchange of experience among countries with similar issues, such as Italy and Romania, plays a crucial role to share best practices and to define correct skill and adequate competences.

Author Contributions: Italian side-G.M. and V.S.: conceptualization and energy issues; S.M.C.: case-studies of the energy renovation; E.M.M. and P.P.R.: seismic issues. Romanian side-E.-S.G., M.S.G., H.P. and V.M.: conceptualization, state-of-the-art, codes review; Z.M., R.P. and M.V.: case-studies. 
Funding: The authors of DICAR acknowledge the results based on the financing provided by the National Research Plan of the Italian Ministers of University and Scientific Research through the Departmental Research Projects of which they are responsible. The authors of NIRD URBAN-INCERC acknowledge the research framework and financial support provided by the Ministry of Research and Innovation under the Nucleu Program CRESC. The authors of University of Architecture and Urbanism "Ion Mincu" acknowledge the results based on the financing provided by Romanian Ministry of Research and innovation in the following contracts: (1) UAUIM Contract no. 23/2008, 2008-2010, PNCDI 2, n. 1511, Program-INNOVATION, module I: Product-system development, Project category: PDP, project type: CDI Oriented: "Passive houses suitable for climatic conditions in Romania-acronym Passive House"; (2) UAUIM Contract no. 21/2008-2011, contract PNCDI 2, no. 22120, 2008-2011, Program 4-partnerships in the priority areas, research direction: D3, domain 2: "Integrated solutions systems for the rehabilitation of buildings / residential neighborhoods-Acronym SIR." (3) The project "Train-to-nZEB: The Building Knowledge Hubs" is funded by the European Union's Horizon 2020 research and innovation programme under grant agreement n. 649810. (4) The project "Fit-to-nZEB: The Building Knowledge Hubs" is funded by the European Union's Horizon 2020 research and innovation programme under grant agreement n. 754059.

Acknowledgments: The present review paper describes some results of the International Research titled "Seismic and Energy Renovation Strategies for Sustainable Buildings". This research has been carried out within the Agreement of Cooperation signed in July 2017 between the University of Catania, the "Ion Mincu" University of Architecture and Urban Planning (Bucharest) and URBAN INCD INCERC-National Institute for Research and Development in Construction, Urban Planning and Sustainable Spatial Development (Bucharest).

Conflicts of Interest: The authors declare no conflict of interest.

\section{Acronyms}

$\begin{array}{ll}\text { BEMS } & \text { Building Energy Management Systems } \\ \text { BIPV } & \text { Building Integrated Photovoltaics } \\ \text { BRB } & \text { Buckling Restrained Braces } \\ \text { CdTe } & \text { Cadmium Telluride } \\ \text { CIGS } & \text { Copper Indium Gallium Selenide } \\ \text { DHW } & \text { Domestic Hot Water } \\ \text { DL } & \text { Damage Limitation } \\ \text { EN 1988 } & \text { Eurocode 8 } \\ \text { ESCO } & \text { Energy Service Company } \\ \text { ETICS } & \text { External Thermal Insulation Composite System } \\ \text { FRP } & \text { Fibre Reinforced Polymer } \\ \text { HDD } & \text { Heating Degree Days } \\ \text { H'T } & \text { transmission heat loss coefficient } \\ \text { HVAC } & \text { Heating, Ventilating and Air Conditioning } \\ \text { NC } & \text { Near Collapse } \\ \text { NTC08 } & \text { “Norme Tecniche per le Costruzioni” enforced in 2008 } \\ \text { KL } & \text { Knowledge Levels } \\ \text { NSC } & \text { Non-Structural Components } \\ \text { nZEB } & \text { nearly Zero Energy Building } \\ \text { PBT } & \text { Pay Back Time } \\ \text { PCM } & \text { Phase Change Materials } \\ \text { PV } & \text { PhotoVoltaic } \\ \text { PV /T } & \text { PhotoVoltaic and Thermal } \\ \text { PGA } & \text { Peak Ground Acceleration } \\ \text { R } & \text { Thermal Resistance } \\ \text { RC } & \text { Reinforced Concrete } \\ \text { RES } & \text { Renewable Energy Sources } \\ \text { SD } & \text { Significant Damage } \\ \text { ST } & \text { Solar Thermal } \\ \text { TIM } & \text { Transparent Insulation Materials } \\ \text { U } & \text { Thermal Trasmittance } \\ \text { VIP } & \text { Vacuum Insulating Panels } \\ & \end{array}$




\section{References}

1. Wikipedia List of 21st-Century Earthuakes. Available online: https://en.wikipedia.org/wiki/List_of_21stcentury_earthquakes\#2009 (accessed on 23 May 2018).

2. Pérez-Lombard, L.; Ortiz, J.; Pout, C. A review on buildings energy consumption information. Energy Build. 2008, 40. [CrossRef]

3. Calvi, G.M.; Pinho, R.; Magenes, G.; Bommer, J.J.; Restrepo-Vélez, L.F.; Crowley, H. Development of seismic vulnerability assessment methodologies over the past 30 years. ISET J. Earthq. Technol. 2006, 43, 75-104.

4. Mazzarella, L. Energy retrofit of historic and existing buildings. The legislative and regulatory point of view. Energy Build. 2015, 95, 23-31. [CrossRef]

5. Salemi, A.; Patania, F.; Cascone, S.; Gagliano, G.; Lo Faro, A.; Lombardo, G.; Moschella, A.; Sapienza, V. Thermal performance of existing buildings in Mediterranean climate area. In Changing Needs, Adaptive Buildings, Smart Cities; POLIScript: Milan, Italy, 2013; pp. 1017-1024.

6. Detommaso, M.; Gagliano, A.; Nocera, F.; Patania, F.; Sapienza, V. Deploy Energy-efficient Technologies in the Restoration of a Traditional Building in the Historical Center of Catania (Italy). Energy Procedia 2014, 62, 62-71. [CrossRef]

7. Sapienza, V. Spontaneous architecture and energetic sustainability: The Aeolian homes of Filicudi Isle. In Proceedings of the ZEMCH-12, Glasgow, UK, 20-22 August 2012; pp. 340-350.

8. Royal Decree n. 193, 18/04/1909. Mandatory Technical and Hygienical Rules for Repair of Existing and New Buildings in the Areas Struck by the Earthquake of 28 December 1908 and others Listed in the Royal Decree of 15/04/1909; Gazzetta Ufficiale n. 95, 22/04/1909; Istituto Poligrafico e Zecca dello Stato: Rome, Italy, 1909. (In Italian)

9. Report of the Commission in Charge for Studying and Proposing Mandatory Building Codes for the Municipalities Struck by the Earthquake of 28 December 1908 and by Others Earlier; Stabilimento Tipo-Litografico del Genio Civile: Rome, Italy, 1909. (In Italian)

10. Royal Decree n. 573, 29/04/1915. Mandatory Technical and Hygienical Rules in the Areas Struck by the Earthquake of 13 January 1915; Gazzetta ufficiale n. 117, 11/05/1915; Istituto Poligrafico e Zecca dello Stato: Rome, Italy, 1915. (In Italian)

11. Ricci, P.; De Luca, F.; Verderame, G.M. 6th April 2009 L'Aquila earthquake, Italy: Reinforced concrete building performance. Bull. Earthq. Eng. 2011, 9, 285-305. [CrossRef]

12. Italian Ministry of Public Works, Ministry Decree. 14/01/2008. Technical Regulations for Constructions; Suppl. Ord. Gazzetta Ufficiale n. 29, 4/02/2008; Istituto Poligrafico e Zecca dello Stato: Rome, Italy, 2008. (In Italian)

13. Italian Ministry of Public Works: Circolare n. 617. 2/02/2009. Commentary on Technical Regulations for Constructions; Istituto Poligrafico e Zecca dello Stato: Rome, Italy, 2009. (In Italian)

14. Presidence of the Council of Ministers of the Italian Republic: Ordinance n. 3431,3/05/2005. Technical Regulations for Design, Assessment and Seismic Upgrade of Buildings; Suppl. Ord. Gazzetta Ufficiale n. 85, 10/05/2005; Istituto Poligrafico e Zecca dello Stato: Rome, Italy, 2005. (In Italian)

15. CEN EN 1998-3, EuroCode 8. Design of Structures for Earthquake Resistance-Part 3: Assessment and Retrofitting of Buildings; European Committee for Standardization: Bruxelles, Belgium, 2005.

16. Italian Ministry of Infrastructure and Transport, Ministry Decree. 21/07/2012. Ratification of National Annexes with Parameters Ascribed for Application of Eurocodes; Suppl. Ord. Gazzetta Ufficiale n. 73, 27/03/2013; Istituto Poligrafico e Zecca dello Stato: Rome, Italy, 2013. (In Italian)

17. Law n. 373/1976. Norme per il Contenimento del Consumo Energetico per usi Termici Negli Edifici; Gazzetta Ufficiale Della Repubblica Italiana n. 148 del 7.6.1976; Istituto Poligrafico e Zecca dello Stato: Rome, Italy, 2015. (In Italian)

18. Law n. 10/1991. Norme per L'attuazione del Piano Energetico Nazionale in Materia di Uso Razionale Dell'energia, di Risparmio Energetico e di Sviluppo Delle Fonti Rinnovabili di Energia; Gazzetta Ufficiale della Repubblica Italiana s.o. n. 13 del 16.1.1991; Istituto Poligrafico e Zecca dello Stato: Rome, Italy, 1991. (In Italian)

19. La Greca, P.; Margani, G. Seismic and energy renovation measures for sustainable cities: A critical analysis of the Italian scenario. Sustainability 2018, 10, 254. [CrossRef]

20. Economidou, M.; Laustsen, J.; Ruyssevelt, P.; Staniaszek, D. Europe's Buildings under the Microscope; BPIE: Brussels, Berlgium, 2011; ISBN 9789491143014. 
21. Finocchiaro, L.; Wågø, S.I. Architectural design and aesthetics of Zero Emission Buildings: An analysis of perceived architectural qualities in the ZEB Living LAB in Trondheim. In Proceedings of the 33rd PLEA International Conference: Design to Thrive, Edinburgh, UK, 3-5 July 2017.

22. Cicero, C.; Lombardo, G. Building envelope and energy. J. Civ. Eng. Arch. 2011, 8, 986-995.

23. Margani, G. L'edificio passivo nel clima mediterraneo. Costruire in laterizio 2011, 141, 46-49.

24. Inter-Ministerial Decree, 26/6/2015. Application of the Calculation Methodology of the Energy Performances and Definition of the Prescription and of the Minimum Required for Buildings; Minister of Economic Development: Rome, Italy, 2015.

25. Legislative Decree n. 28,3/3/2011. Attuazione Della Direttiva 2009/28/CE Sulla Promozione Dell'uso Dell'energia da Fonti Rinnovabili, Recante Modifica e Successiva Abrogazione Delle Direttive 2001/77/CE e 2003/30/CE; Gazzetta Ufficiale della Repubblica Italiana s.o. n. 81 del 28.3.2011; Istituto Poligrafico e Zecca dello Stato: Rome, Italy, 2011. (In Italian)

26. Law 90,3/8/2013. Conversione in Legge, con Modificazioni, del Decreto-Legge 4 Giugno 2013, n. 63, Recante Disposizioni Urgenti per il Recepimento Della Direttiva 2010/31/UE del Parlamento Europeo e del Consiglio del 19 Maggio 2010; Gazzetta Ufficiale della Repubblica Italiana n. 181 del 3.8.2013; Istituto Poligrafico e Zecca dello Stato: Rome, Italy, 2013. (In Italian)

27. Balan, S.; Cristescu, V.; Cornea, I. The Romania Earthquake of 4 March 1977; Editura Academiei: Bucharest, Romania, 1982. (In Romanian)

28. Georgescu, E.S. Earthquake Engineering Development before and after the 4 March 1977, Vrancea, Romania Earthquake. In Proceedings of the 25 years of Research in Earth Physics, Bucharest, Romania, 25-27 September 2002; pp. 93-107.

29. Berg, G.V.; Bolt, B.A.; Sozen, M.A.; Rojahn, C. Earthquake in Romania March 4, 1977. An Engineering Report; National Academy Press: Washington, DC, USA, 1980.

30. Georgescu, E.S.; Pomonis, A. The Romanian Earthquake of 4 March 1977; Revisited: New Insights into its Territorial, Economic and Social Impacts and their Bearing on the Preparedness for the Future. In Proceedings of the 14th World Conference on Earthquake Engineering, Beijing, China, 12-17 October 2008.

31. Code P100-1/2006. Seismic Design Code, Part I-Provisions for the Design of Buildings. Indicative P100-1; Elaborated by UTCB, Endorsed by MDRL; Part I, n. 803 and 803 bis; Official Journal of Romania: Bucharest, Romania, 2006. (In Romanian)

32. Code P100-1/2013. Seismic Design Code_Part I-Provisions for the Design of Buildings. Indicative P100-1 (In Romanian) Elaborated by UTCB, Endorsed by MDRAP; Part I, n. 558 of 03. 09. 2013; Official Journal of Romania: Bucharest, Romania, 2013. (In Romanian)

33. Craifaleanu, I. Romanian Seismic Design Code: Benchmarking Analyses with Reference to International Codes and Research Needs for Future Development. Constructii 2011, 12, 55-64.

34. Craifaleanu, I. Eurocode 8, Part 3 and the Romanian Seismic Code for the Assessment of Existing Buildings, P100-3: Similarities and Differences. Presented at the Workshop Implementation of the EC 8-Part 3: 2005 : Assessment and Interventions, on Buildings in Earthquake Prone Areas, Athens, Greece, 12 April 2013.

35. Code P100-3/2008. Seismic Design Code_Part III_Provisions for Seismic Assessment of Existing Buildings, Indicative P 100-3/2008. Elaborated by UTCB, Endorsed by MDRL; n. 704; Official Journal of Romania: Bucharest, Romania, 2008. (In Romanian)

36. C107/2016. Normative Regarding the Thermal Calculation of Building Elements of Buildings, Indicative C 107-2005, Approved by Order of the Minister of Transports, Constructions and Tourism; n. 2055/2005 Annex A: Climate Zoning of Romania, Annex B: Energy Requirement for Buildings Whose Energy Consumption is Almost Equal to Zero, Modified and Completed by Order of Minister of Regional Development and Public Administration n. 386/28.03.2016; Official Journal of Romania: Bucharest, Romania, 2016.

37. C107/6-2002 General Norm for Calculating the Mass Transfer (Humidity) through the Building Elements; Bulletin of Constructions no. 14/2002; INCERC: Bucharest, Romania, 2002.

38. C107/7-02 Norm for Thermal Stability Design of Building Closures; Bulletin of Constructions no. 8/2003; INCERC: Bucharest, Romania, 2003. 
39. Catalogue of Thermal Bridges SPECIFIC to Buildings; Annex K (Informative) to Order n. 1590/24.08.2012 for the Modification and Completion of Part 3-Normative Regarding the Calculation of Thermal Energy Performance of Building Elements of Buildings, Indicative C107/3 of the Technical Regulation "Normative Regarding the Thermo-Technical Calculation of Building Elements of Buildings" 2005, Approved by the Order of the Minister of Transports, Constructions and Tourism no. 2055/2005; Official Journal of Romania: Bucharest, Romania, 2012.

40. Order of Minister of Regional Development and Public; Administration n. 386/28.03.2016; Official Journal of Romania: Bucharest, Romania, 2016. (In Romanian)

41. Mc 001/2006. Methodology of Buildings Energy Performance Calculation; MTCT Order n. 157, with Annexes 1, 2 and 3, Official Journal of Romania Part I, n. 126 bis, 21.02.2007; Romanian Government: Bucharest, Romania, 2007.

42. C107/2010. Normative Regarding the Thermo-Technical Calculation of Building Elements of Buildings; Indicative C107-2005 Modified by Order n. 2513 of 22 November 2010 for the Amendment of Official Journal of Romania, Part I, n. 820 of 18 December 2010; Romanian Government: Bucharest, Romania, 2010.

43. Possibilities for Reduction of Energy Use for Space Heating of Residential Buildings; IPCT Contract n. $336 / 1992$ (for the Ministry of Public Works), 1992-1994; Ministry of Public Works: Bucharest, Romania, 1992.

44. Decision No. 122/25.02.2016 for Approval of National Plan of Action in the Field of Energy Efficiency; Part I, nr. 169 bis of 11.03.2015; Monitorul Oficial/Official Journal of Romania: Bucharest, Romania, 2016. (In Romanian)

45. Franchin, P.; Pinto, P.E.; Rajeev, P. Confidence factors? J. Earthq. Eng. 2010, 14, 989-1007. [CrossRef]

46. Chopra, A.K. Dynamics of Structures: Theory and Applications to Earthquake Engineering; Prentice Hall: Upper Saddle River, NJ, USA, 2001; ISBN 0-13-086973-2.

47. CEN EN 1998-1, EuroCode 8. Design of Structures for Earthquake Resistance-Part 1: General Rules, Seismic actions and Rules for Buildings; European Committee for Standardization: Bruxelles, Belgium, 2005.

48. Bosco, M.; Ghersi, A.; Marino, E.M. On the evaluation of seismic response of structures by nonlinear static methods. Earthq. Eng. Struct. Dyn. 2009, 38, 1465-1482. [CrossRef]

49. Fajfar, P. Capacity spectrum method based on inelastic demand spectra. Earthq. Eng. Struct. Dyn. 1999, 28, 979-993. [CrossRef]

50. Iervolino, I.; Galasso, C.; Cosenza, E. REXEL: Computer aided record selection for code-based seismic structural analysis. Bull. Earthq. Eng. 2010, 8, 339-362. [CrossRef]

51. Tanganelli, M.; Viti, S.; Mariani, V.; Pianigiani, M. Seismic assessment of existing RC buildings under alternative ground motion ensembles compatible to EC8 and NTC 2008. Bull. Earthq. Eng. 2017, 15, 1375-1396. [CrossRef]

52. Vamvatsikos, D.; Cornell, C.A. Incremental dynamic analysis. Earthq. Eng. Struct. Dyn. 2002, 31, $491-514$. [CrossRef]

53. Garevski, M.; Ansal, A. Earthquake Engineering in Europe. Geotechnical, Geological and Earthquake Enigneering; Springer: Berlin, Germany, 2010; ISBN 978-90-481-9543-5.

54. Dell'umbria, R. Guidelines for Post-Seismic Rehabilitation and Reconstruction of Buildings; Tipografia del Genio Civile: Rome, Italy, 1999; ISBN 88-7722-460-6. (In Italian)

55. Bakis, C.E.; Bank, L.C.; Brown, V.L.; Cosenza, E.; Rizkalla, S.H.; Triantafillou, T.C. Fiber-reinforced polymer composites for construction-State-of-the-art review. J. Compos. Constr. 2002, 6, 73-87. [CrossRef]

56. Barbagallo, F.; Hamashima, I.; Hu, H.; Kurata, M.; Nakashima, M. Base shear capping buildings with graphite-lubricated bases for collapse prevention in extreme earthquakes. Earthq. Eng. Struct. Dyn. 2017, 46, 1003-1021. [CrossRef]

57. Fenz, D.M.; Constantinou, M.C. Behaviour of the double concave Friction Pendulum bearing. Earthq. Eng. Struct. Dyn. 2006, 35, 1403-1424. [CrossRef]

58. Naeim, F.; Kelly, J.M. Design of Seismic Isolated Structures: From Theory to Practice; Wiley \& Sons: New York, NY, USA, 1999; ISBN 978-0-471-14921-7.

59. Kumar, M.; Whittaker, A.S.; Constantinou, M.C. Characterizing friction in sliding isolation bearings. Earthq. Eng. Struct. Dyn. 2015, 44, 1409-1425. [CrossRef]

60. Christopoulos, C.; Filiatrault, A. Principles of Passive Supplemental Damping and Seismic Isolation; IUSS Press: Pavia, Italy, 2006; ISBN 8873580378.

61. Deng, K.; Pan, P.; Nie, X.; Xu, X.; Feng, P.; Ye, L. Study of GFRP Steel Buckling Restraint Braces. J. Compos. Constr. 2015, 19, 04015009. [CrossRef] 
62. Lavan, O. Optimal Design of Viscous Dampers and Their Supporting Members for the Seismic Retrofitting of 3D Irregular Frame Structures. J. Struct. Eng. 2015, 141. [CrossRef]

63. Lee, K.S.; Fan, C.P.; Sause, R.; Ricles, J. Simplified design procedure for frame buildings with viscoelastic or elastomeric structural dampers. Earthq. Eng. Struct. Dyn. 2005, 34, 1271-1284. [CrossRef]

64. Rossi, P.P. Importance of isotropic hardening in the modeling of buckling restrained braces. J. Struct. Eng. 2015, 141. [CrossRef]

65. Xie, Q. State of the Art of Buckling-Restrained Braces in Asia. J. Constr. Steel Res. 2005, 61, 727-748. [CrossRef]

66. Barbagallo, F.; Bosco, M.; Marino, E.M.; Rossi, P.P.; Stramondo, P.R. A multi-performance design method for seismic upgrading of existing RC frames by BRBs. Earthq. Eng. Struct. Dyn. 2017, 46, 1099-1119. [CrossRef]

67. Formisano, A.; Castaldo, C.; Chiumiento, G. Optimal seismic upgrading of a reinforced concrete school building with metal-based devices using an efficient multi-criteria decision-making method. Struct. Infrastruct. Eng. 2017, 13, 1373-1389. [CrossRef]

68. Pan, P.; Li, W.; Nie, X.; Deng, K.; Sun, J. Seismic performance of a reinforced concrete frame equipped with a double-stage yield buckling restrained brace. Struct. Des. Tall Spec. Build. 2017, 26, e1335. [CrossRef]

69. Impollonia, N.; Palmeri, A. Seismic performance of buildings retrofitted with nonlinear viscous dampers and adjacent reaction towers. Earthq. Eng. Struct. Dyn. 2018. [CrossRef]

70. Neri, F.; La Guzza, M.; Russo, A. Use of Dissipative Braces for Seismic Protection of the School Building Cappuccini in Ramacca (CT). On-line Journal GLISNews 2008. Available online: http://www.assisiantiseismicsystems.org/territorial/glis/glisnews/gn11/gn11_cappuccini.pdf (accessed on 29 September 2017). (In Italian)

71. FIP Industriale. Available online: https: / / www.fipindustriale.it/index.php?area=108\&menu=99\&page=228 (accessed on 29 September 2017).

72. Sorace, S.; Terenzi, G.; Magonette, G.; Molina, F.J. Experimental investigation on a base isolation system incorporating steel-Teflon sliders and pressurized fluid viscous spring dampers. Earthq. Eng. Struct. Dyn. 2008, 37, 225-242. [CrossRef]

73. Marshall, J.D.; Charney, F.A. Seismic response of steel frame structures with hybrid passive control systems. Earthq. Eng. Struct. Dyn. 2012, 41, 715-733. [CrossRef]

74. Wolff, E.D.; Ipek, C.; Constantinou, M.C.; Tapan, M. Effect of viscous damping devices on the response of seismically isolated structures. Earthq. Eng. Struct. Dyn. 2015, 44, 185-198. [CrossRef]

75. De Domenico, D.; Ricciardi, G. An enhanced base isolation system equipped with optimal tuned mass damper inerter (TMDI). Earthq. Eng. Struct. Dyn. 2017, 1-24. [CrossRef]

76. Qu, Z.; Wada, A.; Motoyui, S.; Sakata, H.; Kishiki, S. Pin-supported walls for enhancing the seismic performance of building structures. Earthq. Eng. Struct. Dyn. 2012, 41, 2075-2091. [CrossRef]

77. Toranzo-Dianderas, L.A.; Restrepo, J.I.; Carr, A.J.; Mander, J.B. Rocking confined masonry walls with hysteretic energy dissipators and shake-table validation. In Proceedings of the 13th World Conference on Earthquake Engineering, Vancouver, BC, Canada, 1-6 August 2004.

78. Panian, L.; Steyer, M.; Tipping, S. An innovative approach to earthquake safety and concrete construction in buildings. J. Post-Tens. Inst. 2007, 5, 7-16.

79. Stevenson, M.; Panian, L.; Korolyk, M. Post-tensioned concrete walls and frames for seismic-resistance-A case study of the David Brower Center. In Proceedings of the SEAOC Annual Convention, HI, USA, 23-27 September 2008.

80. Balducci, A.; Castellano, M.G. Seismic retrofitting of a RC school building through the "Damping Towers" system. Progettazione Sismica 2015, 6. (In Italian) [CrossRef]

81. Ordinance n. 20/1994. Government Ordinance on Existing Buildings Risk Reduction; Part I, n. 863, Revised, Republished in 19.11.2015; Monitorul Oficial/Official Journal of Romania: Bucharest, Romania, 2015. (In Romanian)

82. Stazi, F.; Vegliò, A.; Di Perna, C.; Munafò, P. Experimental comparison between 3 different traditional wall constructions and dynamic simulations to identify optimal thermal insulation strategies. Energy Build. 2013, 60, 429-441.

83. Baljit, S.S.S.; Chan, H.-Y.; Sopian, K. Review of building integrated applications of photovoltaic and solar thermal systems. J. Clean. Prod. 2016, 137, 677-689. [CrossRef]

84. Tripathy, M.; Sadhu, P.K.; Panda, S.K. A critical review on building integrated photovoltaic products and their applications. Renew. Sustain. Energy Rev. 2016, 61, 451-465. [CrossRef] 
85. Maurer, C.; Cappel, C.; Kuhn, T.E. Progress in building-integrated solar thermal systems. Sol. Energy 2017, 154, 158-186. [CrossRef]

86. Gagliano, A.; Nocera, F.; Patania, F.; Capizzi, A. Assessment of micro-wind turbines performance in the urban environments: An aided methodology through geographical information systems. Int. J. Energy Environ. Eng. 2013, 4, 1-14. [CrossRef]

87. Özkan, H.A. A new real time home power management system. Energy Build. 2015, 97, 56-64. [CrossRef]

88. Sapienza, V.; Rodonò, G. Intesa Sanpaolo Tower. Arketipo 2016, 100, 104-115.

89. Sapienza, V. The new chamber building of Malta: Architectural image and building technology. Techne 2014, 8, 219-227. [CrossRef]

90. Lu, Y.; Wang, S.; Shan, K. Design optimization and optimal control of grid-connected and standalone nearly/net zero energy buildings. Appl. Energy 2015, 155, 463-477. [CrossRef]

91. Gagliano, A.; Patania, F.; Nocera, F.; Capizzi, A.; Galesi, A. GIS-based decision support for solar photovoltaic planning in urban environment Smart Innovation. Syst. Technol. 2013, 22, 865-874. [CrossRef]

92. Caponetto, R.; Caponetto, R.; Cecere, C.; D’Urso, S.; Habib, E.; Margani, G.; Sapienza, V. Automated collecting building envelopes. In ICT, Automation and Industry of the Built Environment: From the Information Exchange to the Field Management; Maggioli Editore: Rimini, Italy, 2013; pp. 340-357, ISBN 88-387-6258-1.

93. Ma, Z.; Cooper, P.; Daly, D.; Ledo, L. Existing building retrofits: Methodology and state-of-the-art. Energy Build. 2012, 55, 889-902. [CrossRef]

94. Complex, Multicriterial, Integrated Rehabilitation of Urban and Housing Complexes. Certification of Sustainable Buildings; “Ion Mincu” University Publishing House: Bucharest, Romania, 2011; ISBN 978-606-638-002-7.

95. Building Knowledge Hubs. Available online: http:/ / www.train-to-nzeb.com (accessed on 30 September 2017).

96. SC 007-2013. Framework Solutions for the Thermo-Hygro-Energetic Rehabilitation of Existing Building Envelope; Part I, no. 540 bis/27.08.2013; Monitorul Oficial/Official Journal of Romania: Bucharest, Romania, 2013.

97. BUILD UP Skills Project Romania (ROBUST). Available online: http:/ / www.iee-robust.ro (accessed on 30 September 2017).

98. BUILD UP Skills QualiShell Project. Available online: http:/ / www.iee-robust.ro/ qualishell (accessed on 29 September 2017).

99. Castellazzi, L.; Zangheri, P.; Paci, D. Synthesis Report on the assessment of Member States' building renovation strategies. In Publications Office of the European Union; UE: Bruxelles, Belgium, 2016; ISBN 978-92-79-54703-4.

100. Caponetto, R.; Margani, G.; Sapienza, V. La riqualificazione energetica dell'edilizia residenziale. Il Progetto Sostenibile 2016, 38, 58-73. (In Italian)

101. Zappalà, S. Librino between district and town. Spazio e Società 1990, 52, 118-121.

102. Takeuchi, T.; Yasuda, K.; Iwata, M. Studies on Integrated Building Facade Engineering with High-Performance Structural Elements. IABSE Symp. Rep. 2006, 92, 33-40. [CrossRef]

103. Takeuchi, T.; Yasuda, K.; Iwata, M. Seismic retrofitting using energy dissipation façades. In Proceedings of the ATC-SEI09, San Francisco, CA, USA, 10-12 September 2009.

104. Leone, M.F.; Zuccaro, G. Seismic and energy retrofitting of residential buildings: A simulation-Based approach. UPLanD 2016, 1, 11-25.

105. Calvi, G.M.; Sousa, L.; Ruggeri, C. Energy Efficiency and Seismic Resilience: A Common Approach. In Multi-Hazard Approaches to Civil Infrastructure Engineering; Springer International Publishing: Cham, Switzerland, 2016; pp. 165-208.

106. Manfredi, V.; Masi, A. Seismic Strengthening and Energy Efficiency: Towards an Integrated Approach for the Rehabilitation of Existing RC Buildings. Buildings 2018, 8, 36. [CrossRef]

107. ProGETone. Available online: https:/ / www.progetone.eu/ (accessed on 29 September 2017).

108. Law 205/2017. Bilancio di Previsione Dello STATO per L'anno Finanziario 2018 e Bilancio Pluriennale per il Triennio 2018-2020; Gazzetta Ufficiale della Repubblica Italiana s.o. n. 302 del 29.12.2017; Gazzetta Ufficiale della Repubblica Italiana: Rome, Italy, 2017. (In Italian)

(C) 2018 by the authors. Licensee MDPI, Basel, Switzerland. This article is an open access article distributed under the terms and conditions of the Creative Commons Attribution (CC BY) license (http:// creativecommons.org/licenses/by/4.0/). 